\title{
Responsibility in Capital Sentencing
}

\author{
STEVEN SEMERARO*
}

\section{TABLE OF CONTENTS}

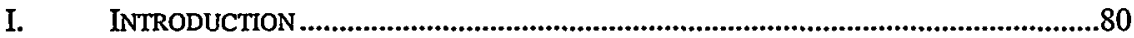

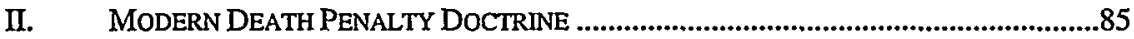

A. Building Modern Doctrine.............................................................................85

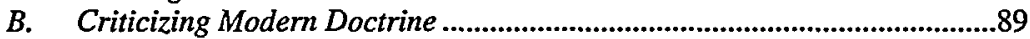

1. Criticism from Within the Court........................................................89

2. Academic Criticism of Death Penalty Doctrine......................................91

III. REINTERPRETING MODERN DOCTRINE: A RESPONSIBILITY THEORY .......................94

A. Identifying the Problem with the Twin Goals:

Consistency and Individualization.............................................................94

B. The Possibility of an Individual-Responsibility-Based

Theory of Capital Sentencing .....................................................................97

1. Traditional American Legal Theory .......................................................99

2. Articulating a Responsibility Theory................................................101

C. The Necessity of an Individual-Responsibility-Based

Theory of Capital Punishment ................................................................105

D. Modern Capital Punishment Doctrine and Responsibility

Theory..

1. The Supreme Court's Discussion of Individual Responsibility.

2. Academic Analysis of Modern Doctrine in Terms of Individual Responsibility.

3. The Ways in Which Modern Doctrine Fosters Responsibility ............114

a. The Legislator's Responsibility .....................................................114

* Assistant Professor of Law at Thomas Jefferson School of Law. J.D., Stanford Law School; B.A., Rutgers College. The author thanks Marjorie Cohn, Ilene Durst, Stephen Garvey, Teresa Gillis, Scott Howe, Eric Mitnick, David Steinberg, and Robert Weisberg for reviewing earlier drafts of this Article and providing helpful comments and encouragement. The author also thanks Donna Brown, Jenny Hernandez, and the students in his Summer 2000 death penalty law class for their research. 
b. The Prosecutor's Responsibility

c. The Sentencer's (Jury's or Trial Judge's)

Responsibility.

d. The Reviewing Court's Responsibility

E. Evaluating the Empirical Critique of Responsibility Theory

F. Evaluating the Radical Subjectivism Critique of

Responsibility Theory

IV. REVISING MODERN DOCTRINE TO COMPORT WITH

RESPONSIBILITY THEORY

A. Strengthening Sentencer Responsibility.................................................129

B. Strengthening the Meaningful Appellate Review

Requirement.

1. The Role of Appellate Review in Capital

Punishment Doctrine

2. Considering Appellate Review of Capital

Cases in Light of the Review Required in

Other Constitutional Cases

a. The Substantive Constitutional Question

in Capital Cases

b. Other Substantive Constitutional Questions...........................140

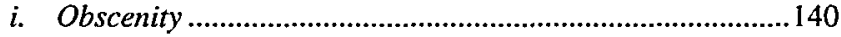

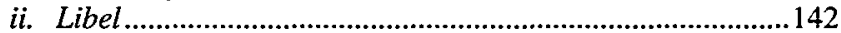

iii. Probable Cause and Reasonable Suspicion ......................... 142

iv. Excessive Fines.................................................................143

v. Punitive Damages .............................................................144

c. No Meaningful Distinctions Justify More

Deferential Review in Capital Cases.

3. Defining the Scope of De Novo Review of

Capital Cases

4. Limiting the De Novo Review Requirement to State

Court

V. CONCLUSION

\section{INTRODUCTION}

Modern capital punishment doctrine has few friends. ${ }^{1}$ A recent Harvard Law Review article summed up the prevailing wisdom by concluding that "[i]t is difficult to imagine a body of doctrine that is much worse-either in its costs of implementation or in its negligible returns - than the one we have now."2 Until recently, however, modern

1. This Article uses the phrase modern capital punishment doctrine to refer to the legal doctrine developed by the United States Supreme Court, beginning in 1976, to govern death penalty cases. That doctrine is summarized infra at Part II.A.

2. Carol S. Steiker \& Jordan M. Steiker, Sober Second Thoughts: Reflections on Two Decades of Constitutional Regulation of Capital Punishment, 109 HARV. L. REV. 355, 426 (1995). Even articles that find some merit or consistency in the Court's doctrine end up arguing that additional safeguards are necessary. See, e.g., F. Patrick Hubbard, "Reasonable Levels of Arbitrariness" in Death Sentencing Patterns: A Tragic 
doctrine was tolerated because many supposed that its elaborate procedures ensured that innocents would not be executed. ${ }^{3}$ The rising tide of evidence to the contrary has left the fate of modern capital punishment doctrine in grave doubt. ${ }^{4}$

One response, of course, would be to do away with capital punishment entirely. ${ }^{5}$ But that seems unlikely. The evidence of innocents on death

Perspective on Capital Punishment, 18 U.C. DAvIS L. REv. 1113, 1161-62 (1985) (concluding that "the constitutional model is a justifiable effort to provide more consistent, less arbitrary results than prior methods," but calling for a more searching review of sentencing patterns).

3. Samuel R. Gross, The Risks of Death: Why Erroneous Convictions Are Common in Capital Cases, 44 BUFF. L. REv. 469, 470 (1996). "Until recently, most judges, lawyers and scholars were willing to believe that the system worked as intended: that wrongful capital convictions were rare, and wrongful executions virtually nonexistent." Id. (citing Frank G. Carrington, NeIther Cruel Nor Unusual 123 (1978)); see also Alex Kozinski \& Sean Gallagher, Death: The Ultimate Run-On Sentence, 46 CASE W. RES. L. REV. 1, 21 \& n.99 (1995) ("[E]rrors that go to guilt or innocence are exceedingly rare in criminal cases, and even more rare in death cases."); Steiker \& Steiker, supra note 2, at 360 ("The public ... presumes that the highly visible continuing involvement of the Supreme Court in regulating capital punishment insures [sic] ... against arbitrary or unjust executions.").

4. Recently, more refined techniques for DNA analysis have demonstrated that an alarming number of death row inmates likely did not commit the crime for which they were awaiting death. Barry C. Scheck, Preventing the Execution of the Innocent: Testimony Before the Senate Judiciary Committee, 29 HoFsTRA L. REv. 1165, 1165-66 (2001). These instances, in which the innocence of death row inmates has been scientifically proven, have brought into focus the many instances in which death sentences have been overturned because of doubts about the defendant's guilt, or because the death penalty may be inappropriate by some other measure. See James S. Liebman, The Overproduction of Death, 100 CoLUM. L. REv. 2030, 2048-51 \& n.84 (2000) (citing sources identifying eighty-nine death row inmates who have been freed since 1973 because of doubts about their guilt). The evidence of older cases in which innocents may have been executed is also being viewed in a new light. See generally Hugo Adam Bedau \& Michael L. Radelet, Miscarriages of Justice in Potentially Capital Cases, 40 STAN. L. REv. 21 (1987).

5. The current crisis poses a more significant challenge to capital punishment than earlier abolitionist arguments. Past arguments rested on subjective notions of an evolving standard of decency, disagreement about the appropriate goals of punishment, and supposed-but never conclusively demonstrated-discrimination. See, e.g., Furman v. Georgia, 408 U.S. 238, 240 (1972) (Douglas, J., concurring); id. at 257-58 (Brennan, J., concurring); $i d$. at 314-15 (Marshall, J., concurring). See generally CHARLES L.

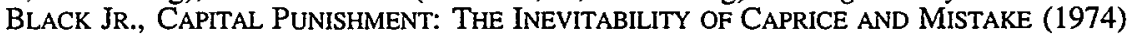
(making the classic argument that the death penalty should be declared unconstitutional because of its arbitrariness and the possibility of mistake). The current challenge rests on a firmer ground, indeed on a principle well-known to the founding fathers-that "one would much rather that twenty guilty persons should escape the punishment of death than that one innocent person should be condemned and suffer capitally." Coffin v. United States, 156 U.S. 432, 455 (1895) (quoting De Laudibus Legum Angliae). Similar formulations of this maxim date back to the Roman Empire-"[I]t was better to let the 
row has produced only calls for moratoriums, until the problems can be fixed. ${ }^{6}$ Public opinion polls continue to show strong, albeit somewhat weakened, support for the death penalty. ${ }^{7}$ The more likely scenario is that capital punishment will continue, perhaps governed by new doctrinal standards. ${ }^{8}$

crime of a guilty person go unpunished than to condemn the innocent." Id. at 454 (quoting Trajan). "[I]t is better five guilty persons should escape unpunished than one innocent person should die." Id. at 456 (quoting Lord Hale). "[T] he law holds that it is better that ten guilty persons escape than that one innocent suffer." Id. at 456 (quoting Blackstone); see also 4 William Blackstone, CommENTARIES *358. More recently, the Supreme Court has used the principle to justify finding that proof beyond a reasonable doubt is a constitutional requirement of due process. See Addington v. Texas, 441 U.S. 418, 423-24 (1979); In re Winship, 397 U.S. 358, 363-64 (1970). The principle was also used to find that a jury of less than six violates the Sixth Amendment. Ballew v. Georgia, 435 U.S. 223, 234 (1978) (relying in part on the fact that it increases "the risk of convicting an innocent person" even though it decreases the "risk of not convicting a guilty person").

6. Several governors and the American Bar Association have called for such a moratorium, but not abolition. ROBERT JAY LIFTON \& GREG MrTCHELL, WHO OWNS DeATH?: CAPITAL Punishment, THE AMERICAN CONSCIENCE, AND THE END OF EXECUTIONS xii (2000); Crystal Nix Hines, Lack of Lawyers Hinders Appeals in Capital Cases: Filing Deadlines Missed-Money Is Scarce and Firms Are Reluctant to Represent Condemned Prisoners, N.Y. TIMES, July 5, 2001, at Al. But see LIFTON \& MrTCHELL, supra, at xii (explaining that the New Hampshire Legislature voted to repeal the state's death penalty, but the governor vetoed the bill).

7. Recent polls show a remarkable consistency of opinion both nationwide and in individual states. About $60 \%$ of respondents say that they support the death penalty. LIFTON \& MITCHELL, supra note 6, at 213 (reporting that polls conducted in early 2000 suggest that $64 \%$ to $66 \%$ favor the death penalty); Death Penalty Informational Center, National Polls: USA Today Poll Finds General Death Penalty Support Down to 59\% (May 4, 2001), available at http://www.deathpenaltyinfo.org/Polls.html (last visited Oct. 23,2001 ) [hereinafter USA Today] (stating that polls conducted in 2000 and 2001 show support for the death penalty in the area of $60 \%$ ). About an equal percentage support a moratorium on executions in light of the recent findings of innocent people on death row. USA Today, supra. The percentage who say they support the death penalty drops to around $50 \%$ when the question presents as an alternative life in prison without parole. Death Penalty Information Center, National Polls: $A B C$ News Poll Finds Drop in Support for Death Penalty and Majority in Favor of Moratorium (Apr. 24, 2001), available at http://www.deathpenaltyinfo.org/Polls.html (last visited Oct. 23, 2001). In a 1997 debate on the death penalty, Judge Alex Kozinski summed up the sentiment that is likely shared by most who support capital punishment: "[I]t is entirely appropriate for society to deem some acts so evil, to be so demeaning of human life, that we can say the perpetrator has forfeited his own life by committing them." The Modern View of Capital Punishment: The Honorable Alex Kozinski vs. Professor Stephen Bright, 34 AM. CRIM. L. REv. 1353, 1355 (1997) (publishing an oral debate held on April 7, 1997 at the Georgetown University Law Center).

8. A leading death penalty scholar has presented a proposal effectively replacing modern doctrine with a ten-point checklist of relatively black and white requirements that state capital punishment systems would be required to meet. Liebman, supra note 4, at $2144-50,2153$ (citing as a benefit of the proposed system "the narrowing of federal post-direct-appeal review to one court and to ten claims based on relatively mechanical and objective requirements"). 
Abandoning current doctrine would be the wrong response. When viewed-as the Court and commentators view it-as a tool to reduce arbitrariness and provide an individualized inquiry into the moral desert of each defendant, current doctrine appears to be riddled with inconsistency and mystery. But the problem lies in the incoherence of those twin goals. Putting them aside and focusing on the doctrine in fresh light reveals the seed of an approach to capital punishment jurisprudence-emphasizing individual responsibility for death-enabling decisions at each step in the process from legislative drafting through appellate review-that, if fully applied, would yield the firmest possible moral foundation for capital punishment. Under this responsibility theory, the role of doctrine would be to place each participant in the sentencing process in an environment in which their sense of responsibility is broadened and with it, our trust in their decision. While this environment would include the trial courtroom, it must also include the legislative chamber, the prosecutor's office, and the appellate courthouse.

Responsibility holds such an important post in the morality of capital sentencing precisely because capital sentencing is a subjective process, perhaps dependent on reflective intuition or on an innate ability to express the punishment a defendant deserves. If the decision to execute were the product of an objective rational calculus, participants in the system could simply do the math. They would need to take responsibility for applying the formula fairly and correctly. But they would not need to assume the deeper responsibility entailed in deciding for themselves whether the decision is right. Because the process is subjective, however, appropriate capital sentencing decisions can only be generated by individuals who take full responsibility for the decisions they make. Responsibility of this sort necessarily requires some level of discretion. It also requires guidance to discourage actors in the process from succumbing to the allure of temptingly easy-to-apply rules of thumb that would enable them to escape the need to grapple with the enormity of a capital sentencing decision.

By this measure, modern doctrine is a marked improvement over the capital sentencing that existed before that doctrine was adopted. Legislatures must now identify specific factors that justify the death penalty; sentencers must not disregard any factor relating to the character or record of the defendant or the circumstances of the crime that call for a lesser sentence, and appellate courts typically provide 
meaningful review. ${ }^{9}$ Each of these doctrinal requirements calls upon actors at different stages of the process to exercise responsibility that was easier to duck under the old capital punishment systems.

Although modern doctrine is worth preserving, ${ }^{10}$ it could be improved significantly by focusing explicitly on heightening individual responsibility. Two concrete ways to improve it would be to (1) explain the sentencer's role in the narrative voice, a way of speaking that, at least in American society, appears to be associated with the assignment of responsibility; and (2) require heightened scrutiny of death sentences by state appellate courts, bringing the responsibility of state appellate judges in capital cases in line with the responsibility they bear in constitutional cases dealing with analogous mixed questions of fact and law under the First, Fourth, Fifth, and Sixth Amendments, as well as in noncapital punishment cases under the Eighth and Fourteenth Amendments.

Part II summarizes modern death penalty doctrine and surveys the wide-ranging criticism of that doctrine both from members of the Court and academic commentators. Part III presents the responsibility theory as an alternative to the Court's misguided pursuit of consistency and individualization in capital sentencing. It explains why individual responsibility is necessary to morally acceptable capital punishment and shows how modern doctrine tends to advance individual responsibility. Concluding subsections respond to likely empirical and theoretical criticisms. Part IV proposes reforms of modern doctrine that would more fully realize the benefits of the responsibility theory.

9. See infra Part III.D.3.a-d.

10. This Article explores the doctrinal criteria to govern capital punishment that is most likely to yield appropriate death sentences. There is ample evidence, however, that in practice, capital punishment systems are more prone to false positive error than other aspects of the criminal justice system for reasons that are unrelated to doctrine and potentially intractable. See Gross, supra note 3, at 477-78 (explaining how "the pressure to solve homicides" tempts investigators "to cut corners ... if they believe they have the killer" and that " $[t]$ he danger that investigators will go too far is magnified to the extent the killing is brutal and horrifying, and to the extent that it attracts public attentionfactors which also increase the likelihood that the murder will be treated as a capital case"). These errors may undermine any potential moral justification for capital punishment. See Richard O. Lempert, Desert and Deterrence: An Assessment of the Moral Bases of the Case for Capital Punishment, 79 MICH. L. REv. 1177, 1125-31 (1981) (arguing that retributivist justification for executing murderers cannot morally justify a state-imposed capital punishment system that is known to produce false positive errors). The doctrinal proposals offered here are unlikely to significantly improve the practical application of capital punishment systems unless the practical problems with the investigation and prosecution of capital crimes are addressed. 


\section{Modern DeAth PENAlty Doctrine}

Until the 1970s, capital punishment systems operated essentially without governing doctrine. ${ }^{11}$ State legislatures rarely did more than identify crimes for which a sentencer could, in its unguided discretion, impose capital punishment. This Part reviews the post-1970 doctrine developed by the United States Supreme Court to govern capital sentencing and surveys criticism of that doctrine.

\section{A. Building Modern Doctrine}

In the 1972 case, Furman v. Georgia, ${ }^{12}$ the Court struck down all then-existing death penalty statutes, holding that vesting unguided discretion in a sentencing jury "created a substantial risk that it would be inflicted in an arbitrary and capricious manner."13 Over the next few years, thirty-five states adopted new death penalty statutes in an attempt to remedy that problem. ${ }^{14}$

In 1976, the Court began the process of building modern capital punishment doctrine through decisions in five cases. ${ }^{15}$ First, in Gregg $v$.

11. In the late $1960 \mathrm{~s}$, the Court did impose two limited requirements. See Witherspoon v. Illinois, 391 U.S. 510, 522 (1968) (holding unconstitutional the practice of excluding jurors who express scruples against the death penalty from capital cases); United States v. Jackson, 390 U.S. 570, 583 (1968) (holding that a statute permitting the defendant to escape the death penalty by pleading guilty is unconstitutionally coercive).

12. 408 U.S. 238 (1972).

13. Gregg v. Georgia, 428 U.S. 153, 188 (1976); id. at 222 (White, J., concurring in judgment) (implying that Furman required a system that would "result in death sentences being imposed with reasonable consistency"); Furman, 408 U.S. at 256-57. The holding in Furman only became clear in 1976 when the Court decided Gregg. The judgment in Furman was announced in a brief per curiam opinion stating that "the imposition and carrying out of the death penalty in these cases constitute cruel and unusual punishment." Furman, 408 U.S. at 239-40. Each of the five justices in the majority wrote their own opinions, and none of the majority Justices joined the opinion of any other. Only two of these justices would have held that the death penalty was per se unconstitutional. Furman, 408 U.S. at 305 (Brennan, J., concurring); id. at 360 (Marshall, J., concurring). The other three did not reach that ultimate question, concluding that the existing procedures resulted in the infliction of cruel and unusual punishment because they were arbitrary, unprincipled, discriminatory, or some combination thereof. Id. at 240-57 (Douglas, J., concurring); id. at 306 (Stewart, J., concurring); id. at 310-13 (White, J., concurring).

14. John W. Poulos, The Supreme Court, Capital Punishment and the Substantive Criminal Law: The Rise and Fall of Mandatory Capital Punishment, 28 ARIz. L. REV. 143, 226-27, 238-41 (1986).

15. See Roberts v. Louisiana, 428 U.S. 325 (1976); Woodson v. North Carolina, 428 U.S. 280 (1976); Jurek v. Texas, 428 U.S. 262 (1976); Proffitt v. Florida, 428 U.S. 
Georgia, the Court rejected the argument that the death penalty per se violated the Constitution. ${ }^{16}$ Second, the Court held that statutes imposing a mandatory death sentence on defendants convicted of certain crimes did violate the Constitution. ${ }^{17}$ And third, the Court upheld three statutes in which states had replaced "arbitrary and wanton jury discretion with objective standards to guide, regularize, and make rationally reviewable the process for imposing a sentence of death."18

The opinions in this third category were the most difficult to interpret. Each of the three states had adopted a system for narrowing the class of death-eligible defendants either by (1) limiting the possibility of a death sentence to certain homicide crimes that were defined more narrowly than first degree murder ${ }^{19}$ or (2) requiring that a jury find an aggravating factor-something about the circumstances of the particular crime or the character or record of the defendant that justified the most severe punishment-in addition to the elements of first degree murder. ${ }^{20}$ Each state also provided a means for jury consideration of the sentence in a separate sentencing proceeding that permitted the introduction of evidence in aggravation and mitigation..$^{21}$ Finally, each state provided an opportunity for meaningful appellate review to guard against arbitrary sentences. ${ }^{22}$

242 (1976); Gregg, 428 U.S. at 153. Each of these cases was announced by a joint opinion signed by three Justices: Stewart, Powell, and Stevens.

16. Gregg, 428 U.S. at 187 ("We hold that the death penalty is not a form of punishment that may never be imposed, regardless of the circumstances of the offense, regardless of the character of the offender, and regardless of the procedure followed in reaching the decision. ..."); see also Roberts, 428 U.S. at 350-56 (White, J., dissenting) (explaining why he believes the death penalty does not violate the Eighth Amendment per se).

17. Roberts, 428 U.S. at 331-36; Woodson, 428 U.S. at 292-305 (holding that mandatory death sentences violate the Eighth Amendment because they (1) were overwhelmingly rejected by the states pre-Furman, (2) merely "papered over the problem" of standardless sentencing because juries would continue to nullify murder convictions in an ad hoc and standardless fashion, where the jury disagreed with the death penalty, and (3) did not provide room for consideration of "compassionate or mitigating factors stemming from the diverse frailties of humankind"); id. at 305-06 (Brennan, J., concurring); id. at 306 (Marshall, J., concurring); see Sumner v. Shuman, 483 U.S. 66, 85 (1987) (rejecting the argument that an inmate serving a life sentence could receive a mandatory death penalty for committing murder).

18. Woodson, 428 U.S. at 303; Jurek, 428 U.S. at 269-74 (reviewing a Texas statute); Proffitt, 428 U.S. at 248-51 (reviewing a Florida statute); Gregg, 428 U.S. at 196-98 (reviewing a Georgia statute).

19. For example, the murder of a police officer. See, e.g., Smith v. Farley, $873 \mathrm{~F}$. Supp. 1199, 1232 (N.D. Ind. 1994) (citing IND. CODE § 35-50-2-9(b)(6)(A) (1979)). 97. 97.

20. Jurek, 428 U.S. at 270-71; Proffitt, 428 U.S. at 248; Gregg, 428 U.S. at 196-

21. Jurek, 428 U.S. at 271-74; Proffitt, 428 U.S. at 248; Gregg, 428 U.S. at 196198.

22. Jurek, 428 U.S. at 269-70; Proffitt, 428 U.S. at 250-53; Gregg, 428 U.S. at 
Despite saying quite a bit about what these states had done, the 1976 opinions ultimately did no more than uphold the death penalty statutes in question. While they made many things relevant to the constitutional inquiry, they did not establish which criteria were essential. ${ }^{23}$ Over the next twenty years, however, the Court derived two relatively clear principles from the 1976 cases that were designed to pursue consistency across capital sentences and individualized consideration of the unique aspects of each crime and defendant. ${ }^{24}$ First, states are required to narrow the class of death-eligible defendants to some subset of all murderers who are more deserving of the death penalty than others. ${ }^{25}$

23. The Court ultimately held that two other practices emphasized in the 1976 opinions-jury sentencing and proportionality review-were not constitutionally required. Spaziano v. Florida, 468 U.S. 447, 459-60 (discussing jury sentencing); see Harris v. Alabama, 513 U.S. 504, 515 (1995) (holding that a trial judge may impose a capital sentence); Pulley v. Harris, 465 U.S. 37, 50-51 (1984) (discussing proportionality review).

Commentators argued in the immediate aftermath of the quintet of cases that the capital punishment systems as actually applied in Georgia, Florida, and Texas could all be found unconstitutional under the principles discussed in the joint opinions in these cases and the cases immediately following them. See generally Randy Hertz \& Robert Weisberg, In Mitigation of the Penalty of Death: Lockett v. Ohio and the Capital Defendant's Right to Consideration of Mitigating Circumstances, 69 CAL. L. REV. 317, 318 (1981) ("[O]f the three state death penalty statutes upheld in the 1976 Cases, none would pass constitutional muster when considered in light of Lockett.").

24. Lowenfield v. Phelps, 484 U.S. 231, 244-46 (1988); McCleskey v. Kemp, 481 U.S. 279, 305-06 (1987). Although the Court has limited its Eighth Amendment doctrine to these two requirements, it has struck down a number of death sentences on other grounds under the Due Process Clause. See Simmons v. South Carolina, 512 U.S. 154,156 (1994) (requiring that the jury be instructed that an alternative to the death sentence is life without possibility of parol where the state introduces evidence of future dangerousness as an aggravating factor); Lankford v. Idaho, 500 U.S. 110, 126-27 (1991) (requiring notice that the sentencer is considering the death penalty prior to the sentencing hearing); Bullington v. Missouri, 451 U.S. 430, 446 (1981) (applying principles of double jeopardy to capital sentencing); Beck v. Alabama, 447 U.S. 625, 638 (1980) (requiring lesser-included-offense instruction where supported by the evidence in a capital case); Green v. Georgia, 442 U.S. 95, 97 (1979) (holding that "the hearsay rule may not be applied mechanistically to defeat the ends of justice" by excluding evidence in mitigation of a death sentence at a capital sentencing trial (quoting Chambers v. Mississippi, 410 U.S. 284, 302 (1973))); Presnell v. Georgia, 439 U.S. 14, 15-17 (1978) (prohibiting imposition of death penalty on the basis of evidence supporting a charge on which no jury finding of guilt was rendered); Gardner v. Florida, 430 U.S. 349, 362 (1977) (holding that a state may not base a death sentence on information not disclosed to the defendant).

25. Godfrey v. Georgia, 446 U.S. 420, 425-26, 432-33 (1980) (plurality) (holding that, where defendant was convicted of killing his wife and mother-in-law with a shotgun after a period of marital strife, "[ $t]$ he petitioner's crimes cannot be said to have reflected a consciousness materially more 'depraved' than that of any person guilty of murder" 
Second, states must hold separate proceedings at which sentencers would be required to consider, and enabled to give effect to, any evidence relating to the character and record of the defendant or the circumstances of the crime that the defendant proffered as a basis for a sentence less than death. ${ }^{26}$

and that "[t]here is no principled way to distinguish this case, in which the death penalty was imposed, from the many cases in which it was not"); see also Arave v. Creech, 507 U.S. 463, 470-471 (1993).

[I]t is not enough for an aggravating circumstance, as construed by the state courts, to be determinate. Our precedents make clear that a State's capital sentencing scheme also must 'genuinely narrow the class of persons eligible for the death penalty.' ... When the purpose of a statutory aggravating circumstance is to enable the sentencer to distinguish those who deserve capital punishment from those who do not, the circumstance must provide a principled basis for doing so.... If the sentencer fairly could conclude that an aggravating circumstance applies to every defendant eligible for the death penalty, the circumstance is constitutionally infirm.

Id. at 474 (citations omitted); see Penry v. Lynaugh, 492 U.S. 302, 327 (1989) (stating in dicta that the capital punishment doctrine is intended to prohibit granting capital sentencers "unbridled discretion"); Maynard v. Cartwright, 486 U.S. 356, 362 (1988) (holding that "channeling and limiting ... the sentencer's discretion in imposing the death penalty is a fundamental constitutional requirement"); California v. Brown, 479 U.S. 538, 541 (1987) (stating in dicta that "death penalty statutes [must] be structured so as to prevent the penalty from being administered in an arbitrary and unpredictable fashion"); Spaziano v. Florida, 468 U.S. 447, 460 (1984) (stating in dicta that states "must administer [the death] penalty in a way that can rationally distinguish between those individuals for whom death is an appropriate sanction and those for whom it is not"); California v. Ramos, 463 U.S. 992, 999 (1983) (stating in dicta that the doctrine is intended to ensure that "the death penalty is not meted out arbitrarily or capriciously"); see also Tuilaepa v. California, 512 U.S. 967, 972-75 (1994) (distinguishing eligibility factors that render a defendant eligible for the death penalty from selection factors that guide the jury in deciding whether to impose a death sentence on an eligible defendant, and holding that the latter need only have "some "common-sense core of meaning ... that criminal juries should be capable of understanding"' (quoting Jurek v. Texas, 428 U.S. 262, 279 (1976))); Shell v. Mississippi, 498 U.S. 1, 1 (1990) (per curiam) (discussing proper limiting instructions for jurors).

26. Penry v. Johnson, 121 S. Ct. 1910, 1920-21 (2001) (holding that a state may not prevent the sentencer from considering and giving effect to evidence relevant to the defendant's background or character or to the circumstances of the offense that mitigate against imposing the death penalty); Hitchcock v. Dugger, 481 U.S. 393, 397-99 (1987); Skipper v. South Carolina, 476 U.S. 1, 5 (1986); Eddings v. Oklahoma, 455 U.S. 104, 113-14 (1982); cf. Mills v. Maryland, 486 U.S. 367, 376, 384 (1988) (holding that a state may not require unanimous agreement on a mitigating circumstance before individual members of the jury may consider it); Franklin v. Lynaugh, 487 U.S. 164, 174 (1988) (plurality) (holding that a state may prohibit consideration of residual doubt about defendant's guilt as a mitigating circumstance); Lockett v. Ohio, 438 U.S. 586, 604 (1978) (plurality) (holding that the sentencer "not be precluded from considering, as a mitigating factor, any aspect of a defendant's character or record and any of the circumstances of the offense that the defendant proffers as a basis for a sentence less than death"); see also McKoy v. North Carolina, 494 U.S. 433, 439-44 (1990) (applying Mills to a North Carolina statute). 


\section{B. Criticizing Modern Doctrine}

There has been no shortage of criticism of capital punishment doctrine, both from the justices and the commentators. The following subsections summarize that criticism.

\section{Criticism from Within the Court}

The first criticism of modern death penalty doctrine came from justices who actually comprised a majority of the Court. Gregg and its companion cases were announced through joint opinions in which only three justices joined. ${ }^{27}$ For a number of years, the rationale for overturning death sentences in most cases was not supported by a majority. ${ }^{28}$

Some justices attacked the constitutional underpinnings of the doctrine. Criminal sentencing had traditionally been a discretionary task subject to very limited review, and these justices saw no constitutional basis for requiring more for capital punishment. ${ }^{29}$ And even if there were a constitutional basis for demanding consistency in capital sentencing, these justices reasoned, there could be no justification for undercutting that requirement by demanding that sentencers consider all mitigating evidence with essentially no guiding standards. ${ }^{30}$ Other

27. Roberts, 428 U.S. 325, 327 (1976); Woodson, 428 U.S. 280, 280 (1976); Jurek, 428 U.S. at 264; Proffitt, 428 U.S. at 244; Gregg, 428 U.S. at 158.

28. Godfrey, 446 U.S. at $422 ;$ Lockett, 438 U.S. at 589; Gardner, 430 U.S. at 351.

29. Gardner, 430 U.S. at 371 (Rehnquist, J., dissenting) ("The prohibition of the Eighth Amendment relates to the character of the punishment, and not to the process by which it is imposed."); Roberts, 428 U.S. at 363 (White, J., dissenting) ("I see no warrant under the Eighth Amendment for refusing to uphold these statutes."); Woodson, 428 U.S. at 321 (Rehnquist, J., dissenting) ("None of the cases half-heartedly cited by the plurality ... comes within a light-year of establishing the proposition that individualized consideration is a constitutional requisite for the imposition of the death penalty."). Justices continue to express this view. See, e.g., Graham v. Collins, 506 U.S. 461, 488 (1993) (Thomas, J., concurring).

30. Lockett, 438 U.S. at $622-23$ (White, J., concurring in part, dissenting in part) ("The Court has now completed its about-face since Furman.... I greatly fear that the effect of the Court's decision today will be to compel constitutionally a restoration of the state of affairs at the time Furman was decided...."). Justice White also expressed concern that requiring discretion not to impose the death penalty no matter what crime is committed "invites a return to the pre-Furman days when the death penalty was generally reserved for those very few for whom society has least consideration." Id. at 623; id. at 631 (Rehnquist, J., concurring in part and dissenting in part) (stating that the holding in Lockett "will not eliminate arbitrariness or freakishness in the imposition of sentences, but will codify and institutionalize it... [I]t will not guide sentencing 
justices bemoaned the doctrine's failure to address meaningfully the goals of consistency and individualization. ${ }^{31}$

Despite this early criticism, modern doctrine was eventually accepted and, for a very brief period in the late 1980 s, two unanimous decisions created an appearance of stability. ${ }^{32}$ Even then, some justices questioned the tension within the doctrine, ${ }^{33}$ and less than two years later, the Court splintered anew. Two justices who had joined the earlier unanimous decisions announced that they would refuse to follow the doctrine in future cases. Justice Scalia concluded that he would no longer apply the individualization branch of the doctrine because it could not be applied in conjunction with the more firmly grounded consistency requirement. ${ }^{34}$ Justice Blackmun agreed that the two branches of doctrine could not be consistently applied, but since he saw both as constitutionally compelled, he refused to vote to uphold any capital sentence. ${ }^{35}$ A majority of the

discretion but will totally unleash it"); Woodson, 428 U.S. at 318-19 (Rehnquist, J., dissenting) (explaining that appellate review cannot eliminate arbitrary decisions not to impose a death sentence).

31. See, e.g., Godfrey, 446 U.S. at 440 (Marshall, J., concurring) ("II]t is now apparent that the defects that led my Brothers Douglas, Stewart, and White to concur in the judgment in Furman are present as well in the statutory schemes under which defendants are currently sentenced to death.").

32. Maynard v. Cartwright, 486 U.S. 356, 363-65 (1988) (unanimously confirming the requirement that the category of defendants eligible for the death penalty must meaningfully be narrowed through clear prerequisites); Hitchcock, 481 U.S. at 397-99 (unanimously confirming the requirement that the sentencer must consider mitigating evidence relating to character and record of the defendant and the circumstances of the crime).

33. See, e.g., Franklin v. Lynaugh, 487 U.S. 164, 182 (1988) (plurality); California v. Brown, 479 U.S. 538, 544 (1987) (O'Connor, J., concurring); McCleskey v. Kemp, 481 U.S. 279, 363 (1987) (Blackmun, J., dissenting).

34. Walton v. Arizona, 497 U.S. 639, 671 (1990) (Scalia, J., concurring in part).

Pursuant to Furman, and in order "to achieve a more rational and equitable administration of the death penalty," we require that States "channel the sentencer's discretion by 'clear and objective standards' that provide 'specific and detailed guidance." In the next breath, however, we say that "the State cannot channel the sentencer's discretion ... to consider any relevant [mitigating] information offered by the defendant," and that the sentencer must enjoy unconstrained discretion to decide whether any sympathetic factors bearing on the defendant or the crime indicate that he does not "deserve to be sentenced to death." The latter requirement quite obviously destroys whatever rationality and predictability the former requirement was designed to achieve.

Id. at 664-65 (alteration in original) (citations omitted). "Since I cannot possibly be guided by what seem to me incompatible principles," he wrote, "I must reject the one that is plainly in error." Id. at 673. Justice Scalia announced that he would henceforth follow only that branch of modern capital punishment doctrine that called for states "to establish in advance, and convey to the sentencer, a governing standard." Id. at 671; see Buchanan v. Angelone, 522 U.S. 269, 279 (1998) (Scalia, J., concurring) ("The Court's ongoing attempt to resolve that contradiction by drawing an arbitrary line in the sand between the 'eligibility and selection phases' of the sentencing decision is, in my view, incoherent and ultimately doomed to failure.").

35. Callins v. Collins, 510 U.S. 1141, 1155 (1994). Like Justice Scalia, Justice 
Court, however, has continued to apply modern doctrine despite recognizing the tension between its two goals.

\section{Academic Criticism of Death Penalty Doctrine}

The voluminous academic attacks on capital punishment doctrine come from many angles. Some critics contend that the doctrine interferes too much with state capital sentencing systems, ${ }^{36}$ and others

Blackmun concluded that the consistency and rationality demanded by Furman are inversely related to the fairness required by Woodson and Lockett. Id. "A step toward consistency is a step away from faimess." Id. at 1149 (Blackmun, J., dissenting). But unlike Justice Scalia, he refused to abandon either goal because "there is a heightened need for both in the administration of death." Id. at 1155. He concluded:

[T] he proper course when faced with irreconcilable constitutional commands is not to ignore one or the other, nor to pretend that the dilemma does not exist, but to admit the futility of the effort to harmonize them. This means accepting the fact that the death penalty cannot be administered in accord with our Constitution.

Id. at 1157; see McCollum v. North Carolina, 512 U.S. 1254, 1256 (1994) (Blackmun, J., dissenting) ("Our system of capital punishment simply does not accurately and consistently determine which defendants most 'deserve' to die.").

36. The framers, this argument runs, would not have needed to impose special procedures for capital crimes through the Fifth Amendment if the Eighth Amendment were intended to regulate capital punishment. See, e.g., RAOUL BERGER, DEATH PEnalties: The Supreme CourT's OBSTACle Course 46-47 (1982). “[S]pecial safeguards in application of the death penalty were provided by the Fifth Amendment precisely because the Framers postulated that the death penalty was unaffected by the Eighth Amendment." Id. at 47; see also Ernest van den Haag, The Death Penalty Once More, 18 U.C. DAvis L. Rev. 957, 957-58 (1984). But see Hugo Adam Bedau, Thinking of the Death Penalty as a Cruel and Unusual Punishment, 18 U.C. DAvis L. REv. 873, 895 (1984) (arguing that language accepting the death penalty in the Constitution "fails to prove ... that it was part of the original intention that the death penalty as such could never be incompatible with the eighth amendment [sic].").

Other commentators have made the more limited argument that, while the Eighth Amendment does require the Court to limit capital sentencing to crimes, defendants, and situations for which it is a proportional punishment, the amendment does not support the Court's specific doctrine. For example, Scott Howe argues that the amendment provides no authority to impose procedural requirements on the states to ensure consistency in capital sentencing. Scott W. Howe, The Failed Case for Eighth Amendment Regulation of the Capital-Sentencing Trial, 146 U. PA. L. REV. 795, 811 (1998).

A practical argument against modern doctrine contends that its complexity permits-if not requires-extended appeals and collateral attacks. Kozinski \& Gallagher, supra note 3 , at 17. The cost of this litigation in terms of judicial, prosecutorial, and defense counsel resources is immense. Id. at 12-16. Both the victim's surviving relatives and the inmates on death row pay a huge emotional price as well, as a result of the delays in the system. See Lackey v. Texas, 514 U.S. 1045, 1045 (1995) (describing awaiting execution on death row as "one of the most horrible feelings to which [a person] can be subjected" (quoting In re Medley, 134 U.S. 160, 172 (1890))); see also Elledge v. Florida, 525 U.S. 944, 945 (1998) (Breyer, J., dissenting) (reasserting the views 
believe the Court has stopped far short of adequately regulating state processes. $^{37}$ One provocative piece argues both, contending that the Court has gone too far in regulating relatively insignificant aspects of capital sentencing, but has not done enough in areas that really matter. ${ }^{38}$ Other commentators have argued that modern doctrine is ineffectual at removing arbitrariness from capital sentencing and has created an illusion of legality that has improperly legitimized the process. ${ }^{39}$ Critics

expressed by Justice Stevens in Lackey); People v. Anderson, 493 P.2d 880, 894, 899 (Cal. 1972) (striking down the pre-Furman capital punishment statute in California, in part because of the "dehumanizing effects of the lengthy imprisonment prior to execution" which were described as "psychological torture"); Dist. Attorney for the Suffolk Dist. v. Watson, 411 N.E.2d 1274, 1287 (Mass. 1980) (Braucher, J., concurring) (relying in part on the delay between sentencing and execution in concluding that the state death penalty should be held unconstitutional); Kozinski \& Gallagher, supra note 3, at 17-18 (discussing the impact of time between sentencing and execution on the victim's family).

37. A number of critiques propose a requirement that states narrow the class of death eligible defendants more carefully, for example, by limiting broad, vaguely worded aggravating circumstances. See generally Stephen P. Garvey, Politicizing Who Dies, 101 YALE L.J. 187 (1991) (criticizing the Court for deferring to state legislatures in the adoption of aggravating circumstances); DAVID C. BALDUS ET AL., EQUAL JUSTICE AND THE DEATH PENALTY: A LEGAL AND EMPIRICAL ANALYSIS 102 (1990) (concluding that ninety percent of pre-Furman death penalty cases in Georgia would have implicated at least one of the aggravating factors rendering a defendant death-eligible under the postFurman Georgia statute); Stephen Gillers, The Quality of Mercy: Constitutional Accuracy at the Selection Stage of Capital Sentencing, 18 U.C. DAVIS L. REV. 1037, 1095-1107 (1985) (criticizing aggravating circumstances that focus on predictions of future behavior, rather than historic facts).

There are other criticisms as well. See, e.g., BALDUS ET AL., supra, at 419; Louis D. Bilionis, Legitimating Death, 91 MiCH. L. REV. 1643, 1647-48 \& n.20-22 (1993) (citing examples); Garvey, supra, at 196-97, 199-204 (discussing prohibiting conclusive presumptions requiring a death sentence when aggravating factors outweigh mitigating factors and criticizing the Court for narrowing the scope of federal habeas review); Gillers, supra, at 1047-95 (arguing that cases upholding judicial sentencing were wrongly decided); Steiker \& Steiker, supra note 2, at 415-16 (requiring states to limit death eligibility criteria to ensure that at least one in ten who fit the criteria is sentenced to die); id. at 421-25 (calling for higher standards for defense counsel). See generally Robert S. Catz, Federal Habeas Corpus and the Death Penalty: Need for a Preclusion Doctrine Exception, 18 U.C. DAVIS L. REV. 1177 (1985) (criticizing the Court's efforts to narrow federal habeas corpus review).

38. Steiker \& Steiker, supra note 2, at 359.

[W] conclude that ... the death penalty is, perversely, both over- and underregulated. The body of doctrine produced by the Court is enormously complex and its applicability to specific cases difficult to discern; yet, it remains unresponsive to the central animating concerns that inspired the Court to embark on its regulatory regime in the first place. ...

... [A]lmost all of the complexity that the Court has injected into death penalty law concerns relatively few aspects of state death penalty practices; Id. important aspects of those practices remain essentially unregulated.

39. Steiker \& Steiker, supra note 2, at 359, 402 (commenting that modern doctrine "invites if not guarantees the same kinds of inequality as the pre-Furman regime" and that "the overall effect of twenty-odd years of doctrinal head-banging has been to 
have also focused on the internal contradictions within the doctrine that have troubled the justices themselves. ${ }^{40}$ Virtually all agree-in the words of Professors Carol and Jordan Streiker-that modern death penalty doctrine has been "a colossal failure."41

Putting aside critical arguments that essentially call for either (1) the abolition of all capital punishment, or (2) the elimination of national regulation of it, a unifying theme in the criticism is that legal doctrine

substantially reproduce the pre-Furman world of capital sentencing"); Robert Weisberg, Deregulating Death, 1983 SUP. CT. REV. 305, 306 ("[T] he Court has reduced the law of the penalty trial to almost a bare aesthetic exhortation that the states just do somethinganything-to give the penalty trial a legal appearance.").

[T]he Court has returned to its pre-Furman view of the penalty decision. It has come very close to restoring as the minimal constitutional model ... the bifurcated proceeding in which the jury gets all the information in which it can have any legitimate interest, but the law offers it no illusory guidance on the decision to kill.

Id. at 395; see also Kozinski \& Gallagher, supra note 3, at 27 ("[W]e're not in a very different position than we were in twenty-three years ago when the Supreme Court wiped the slate clean of all death statutes ....").

40. Vivian Berger, "Black Box Decisions" on Life or Death-If They're Arbitrary, Don't Blame the Jury: A Reply to Judge Patrick Higginbotham, 41 CASE W. RES. L. REV. 1067, 1080 (1991); Samuel H. Pillsbury, Emotional Justice: Moralizing the Passions of Criminal Punishment, 74 CORNELl L. REV. 655, 668 (1989) ("The Court has confronted the discretion dilemma: while giving sentencers discretion allows them to render decisions on improper bases, regulation of sentencing leads to its own form of moral errors resulting from rule rigidity. The choice, therefore, is between two evils."); Margaret Jane Radin, Cruel Punishment and Respect for Persons: Super Due Process for Death, 53 S. CAL. L. REv. 1143, 1150, 1180-81 (1979) ("The achievable or imaginable level of individualization varies inversely with the achievable or imaginable level of consistency."); Steven Semeraro, The Process of Death: Reflections on Capital Punishment Issues in the Tenth Circuit Court of Appeals, 66 DEN. U. L. REV. 563, 56667, 598 (1989) (commenting that "[s]ociety wants predictability and rationality, but craves fairness," that "[i]t has yet to find a way to have both," and concluding that modern doctrine's procedural focus masks the contradiction); Scott E. Sundby, The Lockett Paradox: Reconciling Guided Discretion and Unguided Mitigation in Capital Sentencing, 38 UCLA L. REV. 1147, 1161 (1991).

Robert Schopp argues that the twin goals of consistency and individualization are not inconsistent. Robert F. Schopp, Reconciling "Irreconcilable" Capital Punishment Doctrine as Comparative and Noncomparative Justice, 53 FLA. L. REV. 475, 493-94 (2001) (commenting that "the two requirements of guided discretion to promote comparative justice and of individualized assessment of all evidence relevant to retributive justice are not only consistent with each other, consistent application of the latter constitutes the former"). But he reaches that conclusion only by redefining the individualization requirement to encompass consideration of only those factors reflected in positive law. Id. at 520-24. This truncation of the individualization requirement simply renders it another set of rules that may fail to take account of factors that the legislature might have considered mitigating had it thought of them in advance.

41. Steiker \& Steiker, supra note 2, at 359. 
should dictate rules that would at root help-in the sense of making it easier for-participants in the capital sentencing process to produce more accurate death sentencing decisions. This Article introduces a very different role for capital sentencing doctrine: while it should enable participants in the process, from legislators to appellate courts and governors, to produce-for lack of a better phrase-more appropriate sentencing decisions, ${ }^{42}$ it cannot dictate results and make their jobs easier. On the contrary, the doctrine should enable more appropriate sentences by making each participant's job very, very hard. It can do this by fostering an environment in which responsible decision-making is demanded. The process will not be pleasant for individuals participating in it. But their decisions will be more worthy of trust. The next Part explores the contours of a responsibility theory of capital punishment and shows how modern doctrine has-perhaps inadvertently-fostered responsibility at various stages of the process.

\section{REINTERPRETING MODERN DOCTRINE: A RESPONSIBILITY THEORY}

This Part begins by identifying the inadequacy of the Court's goals of consistency and individualization. It then postulates an alternative goal-to heighten the individual responsibility of legislators, prosecutors, jurors, and appellate courts. The subsections explaining this alternative goal examine the tendency of American legal theory to describe legal systems that function consistently without relying on individual responsibility. They then explore an alternative conception of a legal system that demands responsible participants and conjectures that incorporating responsibility may be necessary-despite American legal traditions to the contrary-when the law demands decisions on stark moral questions. Next, they explain how modern doctrine has in fact heightened the individual responsibility of participants in the process compared to pre-Furman capital sentencing. The final two subsections respond to likely empirical and theoretical criticisms.

\section{A. Identifying the Problem with the Twin Goals: Consistency and Individualization}

The Court's attempt to reduce arbitrariness and preserve individualized consideration of all relevant factors bearing on the defendant's personal moral responsibility has resulted in theoretical gridlock in capital

42. Because capital sentencing decisions are not the product of a rational calculus, use of the term accurate seems inappropriate. The better descriptive of the quality of a capital sentencing decision is appropriate. 
punishment doctrine. ${ }^{43}$ The way out must recognize that the problem is not the Court's doctrine, but its goals. The words consistency and individualization are used appropriately to express relationships between legal systems. One system can be more (or less) arbitrary or more (or less) open to individuating factors. ${ }^{44}$ But these terms cannot describe an absolute quality of a particular system. Because we can say that one system may be more arbitrary than another, we fool ourselves into thinking that we can also conceive of and describe a system as absolutely consistent, and vice versa. ${ }^{45}$

43. In Robert Weisberg's words:

Capital punishment is at once the best and worst subject for legal rules. The state's decision to kill is so serious, and the cost of error so high, that we feel impelled to discipline the human power of the death sentence with rational legal rules. Yet a judge or jury's decision to kill is an intensely moral, subjective matter that seems to defy the designers of general formulas for legal decision.

Weisberg, supra note 39 , at 308 .

44. While one could argue for a system that was neither too arbitrary nor too individuating, the Court's jurisprudence does not suggest that it has been seeking a balancing point on a continuum. Rather, the Court has required both that "the sentence... should reflect a reasoned moral response to the defendant's background, character, and crime," Penry v. Lynaugh 492 U.S. 302, 319 (1989), and that "[t]he State ... 'channel the sentencer's discretion by clear and objective standards that provide specific and detailed guidance, and that make rationally reviewable the process for imposing a sentence of death."' Arave v. Creech, 507 U.S. 463, 471 (1993) (quoting Godfrey v. Georgia 446 U.S. 420,428 (1980)). While there are also indications in the opinions that the Court is not requiring perfect systems, it appears to be seeking systems that are both consistent and individuating in some absolute sense. See Joseph L. Hoffman \& William J. Stuntz, Habeas After the Revolution, 1993 SUP. CT. REV. 65, 120-21 (distinguishing between doctrine that merely requires some measure of consistency with one seeking a "precise "fit" between defendant and sentence). Commentators, too, appear to have assumed that some sort of absolutely consistent and individuating system is (or should be) the goal of modern doctrine. See, e.g., Radin, supra note 40 , at $1150,1180-81$.

45. This is an attempt to think about the language used to describe capital punishment systems in a way that is often associated with Ludwig Wittgenstein. See LudWIG Wittgenstein, Philosophical Investigations II 109 (G.E.M. Anscombe trans., 3d ed. 1972). He describes his effort to understand philosophical problems by "looking into the workings of our language, and that in such a way as to make us recognize those workings: in despite of an urge to misunderstand them. The problems are solved, not by giving new information, but by arranging what we have always known." Id. Of course, one may be more directly influenced by A.A. Milne:

"The question is, What are we to do about Kanga?"

"The best way," said Rabbit, "would be this. The best way would be to steal Baby Roo and hide him, and then when Kanga says, 'Where's Baby Roo?' we say, "Aha!"'

"Aha!" said Pooh, practising. "Aha! Aha! ... Of course," he went on, "we 
Consistent legal systems and wholly individuating legal systems may be the dragons and the unicorns of legal theory. We can spend an enormous amount of time contemplating what they might be like. But they almost certainly can never exist. Legal systems govern interactions between members of a society. As such, the system must employ language. But language is generalization. We call things by the same name, though we can imagine reasons to treat them differently. As a result of this generalization, no legal system can truly take account of all individuating factors because some factors will always be lost in the generality of language. For much the same reason, no system can ever be entirely consistent. No matter how detailed the set of linguistic rules developed to govern interaction in the system, the rules will invariably include generalities that will fail to take account of factors that would need to be considered to produce a truly consistent system. ${ }^{46}$

The author emphasizes the reference to truly individuating or consistent legal systems, because it may be senseless to speak of even the concept of a system that is absolutely one or the other. Given that individuals organize their thoughts through the generalizations of language, it is possible that we cannot even really imagine what a truly consistent or individuating system would be like, much less actually create one. ${ }^{47}$ It is not just that one system cannot produce results that are both unique and consistent at the same time, ${ }^{48}$ it may be that no

could say 'Aha!' even if we hadn't stolen Baby Roo."

....

$\ldots$

"We say "Aha!" [Rabbit explained] so that Kanga knows that we know where Baby Roo is. 'Aha!' means 'We'll tell you where Baby Roo is, if you promise to go away from the Forest and never come back."' ...

Pooh went into a corner and tried saying 'Aha!' ... Sometimes it seemed to him that it did mean what Rabbit said, and sometimes it seemed to him that it didn't. "I suppose it's just practice," he thought. "I wonder if Kanga will have to practise too so as to understand it." A.A. MILNE, WINNIE-THE-POOH 93 (1926).

46. Frederick Schauer, Playing BY THE RULES: A PHLOSOPHICAL EXAMINATION OF RULE-BASEd DEcision-MAKING IN LAW AND IN LIFE 50 (1991) ("This under- and over-inclusiveness [of rule-based systems] ... is largely ineliminable, the product of entrenchment and not simply of how specific or how general a rule happens to be."); see id. at 50 n. 14 ("But rules achieve clarity, certainty, and determinateness, at the price of including either more or fewer cases in the legal categories defined by the rules than the rationale underlying the rule calls for." (quoting GERALD J. POSTEMA, BENTHAM AND THE COMMON LAW TRADITION 447 (1986))).

47. Try performing a thought experiment in which you conceive of and describe what an absolutely consistent or absolutely individuating system would be like. At a very high level of generality, you will likely be able to imagine such a system. But as you start thinking about what a particular system might look like, the mental picture will blur.

48. Weisberg, supra note 39 , at 327.

The Court had put itself between a rock and a hard place. Furman demanded 
system-in theory, much less in fact-can produce results that are either one. While the question whether a consistent or individuating system could exist in theory is perhaps more appropriate for philosophers than lawyers, the impossibility of achieving a system of either absolute type in practice is enough to justify rejecting the Court's goal of achieving both.

\section{B. The Possibility of an Individual-Responsibility-Based Theory of Capital Sentencing}

If the metagoal of capital punishment doctrine is to ensure that death sentences reflect an appropriately reasoned moral judgment that a particular defendant deserves to die, ${ }^{49}$ individualization and consistency should be replaced with the goal of maximizing the individual responsibility of each decision-maker in the capital sentencing process. Responsibility is important to ensuring a morally grounded decision because decision-making differs in significant ways depending on the level of responsibility the decision-maker perceives he has for the outcome. ${ }^{50}$ Psychological research shows that individuals with perceived responsibility will make more reflective, carefully considered decisions. ${ }^{51}$ They will take more time and avoid the biases that may,

horizontal equity among capital murderers, thereby calling for formal rules of law governing their sentences. Similar people and crimes must be treated similarly. But a rule that treats similar people similarly is a categorical generalization which cannot account for uniqueness. A person cannot be both Id. "unique" and "equal."

49. The concept of deserts with capital punishment doctrine extends beyond the mental state with which the defendant acted to encompass as full a consideration as possible of the defendant's entire life experience and place in the community. See Penry, 492 U.S. at 319, 327-28; Eddings v. Oklahoma, 455 U.S. 104, 110, 112 (1982); Woodson v. North Carolina, 428 U.S. 280, 303-04 (1976); Schopp, supra note 40, at 492 (recognizing that the Court's opinions "identify considerations of character, record, circumstances, background, impairment, duress, emotional pressure, and provocation as relevant to ... culpability[; t]hus, these opinions apparently contemplate a relatively broad notion of culpability as blameworthiness or desert").

50. Steven J. Sherman, The Capital Jury Project: The Role of Responsibility and How Psychology Can Inform the Law, 70 IND. L.J. 1241, 1242 (1995). For example, people respond differently to crime and accident victims depending on their level of perceived responsibility. David $\mathrm{R}$. Shaffer et al., Intervention in the Library: The Effect of Increased Responsibility on Bystanders' Willingness to Prevent a Theft, 5 J. APPLIED SOC. PSYCHOL. 303 (1975).

51. At least one commentator has argued that enhancing responsibility would likely reduce death sentences because responsible decision-makers tend to minimize 
perhaps unconsciously, control less thoughtful, more snap judgments. ${ }^{52}$

The role of legal doctrine should be to ensure that each actor in the process assumes an appropriate degree of individual responsibility for his or her role. The challenge for doctrine builders is to overcome the tendency for individuals - including legislators, prosecutors, ${ }^{53}$ jurors ${ }^{54}$ and judges ${ }^{55}$ - to seek out ways to lessen their sense of responsibility. ${ }^{56}$

negative outcomes, and the imposition of a death sentence is the most likely perceived negative outcome. Sherman, supra note 50, at 1242-43. It is unclear, however, why a juror would necessarily view the imposition of a death sentence as more of a negative outcome than permitting a brutal murderer to possibly kill again-inside or outside the penitentiary system. See Robin West, Taking Freedom Seriously, 104 Harv. L. Rev. 43, 91 (1990) ("It does not follow from this reasoning that the responsible juror, moved by a sympathetic understanding of the defendant's circumstances, will necessarily opt for life over death. The juror must be responsible to and for the entire community, not just the defendant before her."); Theodore Eisenberg et al., Jury Responsibility in Capital Sentencing: An Empirical Study, 44 BuFF. L. REv. 339, 378 (1996) ("We thus cannot reject the hypothesis of no significant relationship between jurors' perceptions of responsibility and the sentencing outcome.").

52. For example, psychologists have found that individuals use more complex judgment strategies rather than simple heuristic principles when they perceive a greater sense of responsibility for their decision. Philip E. Tetlock \& Jae Il Kim, Accountability and Judgment Processes in a Personality Prediction Task, 52 J. PersonAlitY \& Soc. PSYCHOL. 700 (1987). A sharing of responsibility among a group, either among jurors or among participants at different levels in the system, is also problematic because common or group responsibility is more likely to yield "polarized" and "extreme decisions." Sherman, supra note 50, at 1246 \& nn.21-22.

53. See, e.g., Michael Leonard \& Robert Robertson, The Death Penalty: Personal Perspectives, 22 LoY. U. CHI. L.J. 1, 14-15 (1990) (citing interviews with prosecutors who claim that filing death cases is simply "part of their duties").

54. Mark Costanzo \& Sally Costanzo, The Death Penalty: Public Opinions, Legal Decisions, and Juror Perspectives, in VIOLENCE AND THE LAW 246, 264-65 (Mark Costanzo \& Stuart Oskamp eds., 1994) (describing that many jurors "discount their own sense of responsibility for the verdict"- "[i]t was more comforting to focus on the questions"'); Joan W. Howarth, Deciding to Kill: Revealing the Gender in the Task Handed to Capital Jurors, 1994 WIS. L. REv. 1345, 1376-77; Anthony Paduano \& Clive A. Stafford Smith, Deathly Errors: Juror Misperceptions Concerning Parole in the Imposition of the Death Penalty, 18 Colum. Hum. RTS. L. Rev. 211, 213 n.3 (1987) (citing studies that suggest that many jurors do not believe that any death sentence rendered will actually be carried out).

55. Seth Kaberon, The Death Penalty: Personal Perspectives, 22 LOY. U. CHI. L.J. $34,36,38$ (1990) (citing statements by judges that death cases are determined by the evidence and that the judge does not "have any control over the evidence," and "as a judge[,] sworn to uphold the law, [he] must impose death in the proper circumstances").

56. Indeed, this phenomenon likely extends well beyond capital sentencing to other areas where individuals are required to make decisions that affect others in morally significant ways. For example, doctors making civil commitment and termination-ofmedical-treatment decisions may also attempt to "escape the dilemma when the law offers them the 'choice to be choiceless' through a mechanical formula of decision cloaked in the rhetoric of professional authority." Weisberg, supra note 39 , at 393 . It is important to question whether any of these actors succeed or just use post hoc rationalization to help deal with the dilemma. Costanzo \& Costanzo, supra note 54, at 268-69 (explaining that jurors often feel remorse and sorrow and suffer from nightmares, insomnia, and posttraumatic stress disorder); William S. Geimer \& Jonathan 
This subsection first places modern doctrine in the context of American legal theory, which lacks a well-developed concept of individual responsibility. It then explores how a concept of individual responsibility could be incorporated into American legal thinking about the death penalty. The following subsection then explores why incorporating individual responsibility into capital punishment theory is necessary, and why the Court has, perhaps unconsciously, developed doctrine that serves the responsibility theory much better than the goals the Court has been ostensibly pursuing.

\section{Traditional American Legal Theory}

American legal theory has been dominated by two distinct ways of thinking, sometimes called: (1) rights theory, and (2) democratic theory. ${ }^{57}$ Rights theory recognizes that individuals possess rights that the government must respect, through court enforcement if necessary. Rights may exist as a matter of positive law set forth in the specific language of a constitution or statute. Alternatively, rights may be an expression of the morality of a society. On this more expansive view, rights not specifically enumerated in the language of legal texts can be identified by looking to the moral values that led to the declaration of the rights that are directly set out. In either case, individuals are entitled to have their rights upheld irrespective of the individual or collective desires or welfare of others. 58

Democratic theory places faith in the decisions of elected bodies to act in the public interest and trusts courts to interpret laws generated by these elected bodies. Like rights theory, democratic theory has two branches: (1) pluralism, and (2) republicanism. ${ }^{59}$ Pluralism assumes that democratic institutions act in the public interest because elected officials can discover, sum, and implement the individual interests and desires of their constituents. Republicanism assumes that elected bodies will reach

Amsterdam, Why Jurors Vote Life or Death: Operative Factors in Ten Florida Death Penalty Cases, 15 AM. J. CRIM. L. 1, 46 (1987-88).

57. See generally RONALD DwORKIN, TAKING RiGHTS SERIOUSLY 14 (1978) (articulating rights-based American legal theory); Cass R. Sunstein, Interest Groups in American Public Law, 38 STAN. L. REV. 29 (1985) (exploring the history of democratic legal theory in America); Robin West, supra note 51, at 43 (distinguishing rights-based and democratic legal theory).

58. See sources cited supra note 57.

59. Steven Semeraro, Demystifying Antitrust State Action Doctrine, 24 HARV. J.L. \& PUB. POL'Y 203, 215-17 (2000) (distinguishing pluralism and republicanism). 
public-interested decisions through a process of open-minded debate. But those decisions may not accord in any mathematical sense to the individual preferences of the legislators' constituents. ${ }^{60}$

Markedly absent from American legal theory is a concept of individual responsibility. ${ }^{61}$ Individual rights-whether based in positive law or morality-extend to everyone whether they act responsibly or not. Also, while individuals must respect the rights of others, they need not take responsibility for their own actions in the sense that the required code of conduct is defined for them by the definition of the existing rights. As Robin West has written: "We need not understand, much less sympathize, with the subjective experience of our fellow right-holder, because we give him his due when we accord him his rights, and his rights, by right, insulate him from the psychic invasion such sympathetic understanding of his subjectivity would implicate." 62

Pluralism, like rights talk, diminishes responsibility by permitting selfinterest to control individual behavior. Constituents bear no responsibility for their preferences; they simply cast votes for legislators who they believe will advance those preferences. And elected officials too take no real responsibility for their actions. They are incentivized by the desire for votes and reelection. Public actors simply advance interests that are dictated to them by their constituents.

Even republicanism requires only a very truncated form of individual responsibility among elected officials. They must maintain a level of open-mindedness throughout the process of debate, but no general assumption of personal responsibility outside the governmental process is necessary.

Criticism of death penalty doctrine is an outgrowth of American legal theory. Within a rights-centered framework, the critic sees conflicting rights to a capital sentencing system that is both (1) consistently governed by a strict rule of law, and (2) flexible, so as to account for all

60. See Frank Michelman, Law's Republic, 97 YaLE L.J. 1493, 1508 (1988).

[I]n pure pluralist vision, good politics does not essentially involve the direction of reason and argument towards any common, ideal, or selftranscendent end. For true pluralists, good politics can only be a market-like medium through which variously interested and motivated individuals and Id. groups seek to maximize their own particular preferences.

61. Legal theorists contend that responsibility is essential to the proper operation of the rule of law. But they appear to apply a narrower definition of responsibility that consists merely of the ability to comprehend and follow rules. LON L. FULLER, THE MORALITY OF LAW 162 (rev. ed. 1969) ("To embark on the enterprise of subjecting human conduct to the governance of rules involves of necessity a commitment to the view that man is, or can become, a responsible agent, capable of understanding and following rules, and answerable for his defaults.").

62. West, supra note 51 , at 71 . 
individual factors. The two rights are contradictory. There is no balance. Strict rules remove flexibility, and flexible standards are utterly inconsistent with clear rules. Within this realm, either Justice Scalia or Justice Blackmun must be right. ${ }^{63}$ Either defendants facing the death penalty do not have an entitlement to both rights - as Justice Scalia has concluded-or the death penalty must be prohibited because courts cannot enforce both rights-as Justice Blackmun has concluded.

From a democratic perspective, modern doctrine seems entirely unnecessary. Pre-Furman, one could argue that the legislature had failed to meaningfully make the law. ${ }^{64}$ By simply making capital punishment available in murder and rape cases, the legislature was effectively passing the law-making function to juries. Modern doctrine, however, is sufficiently law-like to satisfy either pluralist or republican conceptions of the legislative role. ${ }^{65}$

\section{Articulating a Responsibility Theory}

Given the dominant strains in American legal theory, one should not be surprised that modern capital punishment doctrine has virtually no supporters. Under either a rights- or democracy-driven theory, it is unsupportable.

An entirely different perspective on modern capital punishment doctrine can be attained by abandoning dominant American legal theory and replacing it with a theory that demands and assumes individual responsibility. Although this approach is rare in academic legal theory, the concept is innately understood by jurists and has been articulated eloquently in the writings of Václav Havel. ${ }^{66}$

A key example of a judicial application of the concept is the preFurman case, McGautha v. California. ${ }^{67}$ There, the Court rejected a due process challenge to capital sentencing schemes that provided for unguided jury discretion. ${ }^{68}$ The Court reasoned that providing

63. See supra notes 34-35 and accompanying text.

64. See Furman v. Georgia, 408 U.S. 238, 314 (1972) (White, J., concurring) ("Legislative 'policy' is thus necessarily defined not by what is legislatively authorized but by what juries and judges do in exercising the discretion so regularly conferred upon them.").

65. See Gregg v. Georgia, 428 U.S. 153, 221-22 (1976) (White, J., concurring).

66. See infra notes $72-88$ and accompanying text.

67. 402 U.S. 183 (1971).

68. The trial judge instructed the jury as follows:

Notwithstanding facts, if any, proved in mitigation or aggravation, in 
meaningful guidance would be impossible. "To identify before the fact those characteristics of criminal homicides and their perpetrators which call for the death penalty, and to express these characteristics in language which can be fairly understood and applied by the sentencing authority," Justice Harlan wrote for the Court, "appear to be tasks which are beyond present human ability." "69 But McGautha was more than an exhortation of the futility of legal doctrine. On the contrary, it was an affirmation of faith that individuals compelled to decide whether another person should live or die would take that responsibility seriously. When jurors are "confronted with the truly awesome responsibility of decreeing death for a fellow human," the Court must have believed that jurors possess an innate capacity to empathize with a capital defendant and comprehend the values of the community, and that this capacity is a better moral compass for death sentences than any preset standards a detached legislature might devise. ${ }^{70}$ That conclusion was not based on rights analysis or democratic theory. It looked directly to our innate capabilities as human beings to exercise responsibility for monumental decisions. $^{71}$

determining which punishment shall be inflicted, you are entirely free to act according to your own judgment, conscience and absolute discretion....

... [T] he law itself provides no standard for the guidance of the jury in the selection of the penalty, but, rather, commits the whole matter of determining which of the two penalties shall be fixed to the judgment, conscience, and absolute discretion of the jury.

Id. at $189-90$.

69 . Id. at 204.

70. Id. at 208; see Joseph L. Hoffmann, Where's the Buck?-Juror Misperception of Sentencing Responsibility in Death Penalty Cases, 70 IND. L.J. 1137, 1156 (1995) (reading Justice Harlan's opinion in this way).

71. Weisberg, supra note 39, at 312 ("Harlan does not say that a jury's decision to kill is inevitably irrational. He says with some confidence that as jurors face so obviously awesome a decision they will naturally act with appropriate moral seriousness, guided by at least intuitive moral rationality."). In Caldwell v. Mississippi, the other Supreme Court case to touch on responsibility, the Court declared that it assumed the sentencer would be responsible and cited numerous state cases reflecting the importance of preserving the jurors' sense of responsibility for their task. 472 U.S. 320, 333, 334 n.4 (1985); see, e.g., People v. Myers, 729 P.2d 698, 711-12 (Cal. 1987) (commenting that an instruction informing the jury about commutation improperly "diminish[es] the jury's appreciation of its personal responsibility for the sentencing decision"); Fleming v. State, 240 S.E.2d 37, 40 (Ga. 1977) (holding that "this type of remark [lessening juror's sense of responsibility] has an unusual potential for corrupting the death sentencing process"); Ward v. Commonwealth, 695 S.W.2d 404, 408 (Ky. 1985) (holding that "the prosecutor clearly sought to divert from the minds of the jurors their true responsibility in this case by implying that the ultimate responsibility would fall to the trial judge, this court, [or] other appellate courts" and that "[t]his is clearly an error of reversible magnitude"); State v. Berry, 391 So. 2d 406, 418 (La. 1980) (holding that comments lessening jurors' sense of responsibility deny the defendant "a fair trial in the sentencing phase, and the penalty should be vacated"); Wiley v. State, 449 So. 2d 756, 762 (Miss. 1984) ("While a jury is not literally 'the hangman,' only they may supply the hangman's victims. All notions of 
A fuller understanding of an individual responsibility-driven legal theory can be derived from the political writings of Václav Havel. ${ }^{72}$ Havel elevates responsible individual decisionmaking above both individual rights and democratic institutions as the fountainhead of an alternative to what he called "post-totalitarian"-or later, "advanced totalitarian"--society in Eastern Europe in the late 1970s and early-tomid 1980s. ${ }^{73}$ He urged his society to strive to:

\begin{abstract}
plac[e] ... responsibility above our desires, in making human community meaningful, in returning content to human speaking, in reconstituting, as the focus of all social action, the autonomous, integral, and dignified human "I," responsible for ourselves because we are bound to something higher, and capable of sacrificing something, in extreme cases even everything, ... for the sake of that which gives life meaning. ${ }^{74}$
\end{abstract}

justice require that the jurors as individuals, and as a body, recognize and appreciate the gravity of their role."); Hill v. State, 432 So. $2 d$ 427, 439 (Miss. 1983) ("Any argument by the state which distorts or minimizes this solemn obligation and responsibility of the jury is serious error.... [I]n a death penalty case a jury should never be given false comfort that any decision they make will, or can be, corrected."). More recent cases have criticized certain religious analogies in prosecutorial argument for lessening the jury's sense of responsibility. See Sandoval v. Calderon, 231 F.3d 1140, 1151 (9th Cir. 2000) (holding that "delegation of the ultimate responsibility for imposing a sentence to divine authority undermines the jury's role in the sentencing process"); Buttrum v. Black, 721 F. Supp. 1268, 1316 (N.D. Ga. 1989); People v. Hill, 952 P.2d 673, 692-93 (Cal. 1998); People v. Wash, 861 P.2d 1107, 1134-36 (Cal. 1993); Carruthers v. State, 528 S.E.2d 217, 221-22 (Ga. 2000).

72. Havel's comment in a 1987 interview that " $I$ 'm against anything that serves to cloud personal responsibility" captures well the essence of his thinking. VÁCLAV HAVEL, On the Theme of an Opposition, in OPEN LeTTERS: SELECTED WRITINGS 19651990 at 25 (Paul Wilson ed., 1991). Robin West first looked to Havel's writing as a basis for incorporating a responsibility-based legal theory into American law in Taking Freedom Seriously. West, supra note 51, at 63-71.

73. Havel's understanding of responsibility is quite broad. He saw individuals as responsible not just for their own decisions but for the state of the society in which they live "through the daily personal decisions of each responsible human being which went to create the total state of affairs." VÁClAV HAVEL, "Dear Dr. Husak," in OPEN LETTERS: SELECTED WRITINGS 1965-1990 at 50, 81 (Paul Wilson ed., 1991) (quoting an April 1975 open letter to Dr. Gustav Husak, then general secretary of the Czechoslovak Communist Party).

74. VÁclay Havel, Politics and Conscience, in OPEN LetTers: Selected WRITINGS 1965-1990 at 249, 263 (Paul Wilson ed., 1991) [hereinafter HAVEL, Politics] (quoting a 1984 speech written to acknowledge an honorary doctorate awarded by the University of Toulouse). In The Power of the Powerless, a 1978 essay to stimulate discussion on the subject of freedom and power in eastern Europe, he stated "it is not just the expression of an introverted, self-contained responsibility that individuals have to and for themselves alone, but responsibility to and for the world." VÁCLAV HAVEL, The Power and the Powerless, in OPEN LETTERS: SELECTED WRITINGS 1965-1990 at 125, 194 (Paul Wilson ed., 1991) [hereinafter HAVEL, The Power]. 
Havel contrasts this vision of individual responsibility with a system in which individuals look to government not as a device to enable them to "realize themselves as human beings, but so they may surrender their human identity in favor of the identity of the system." individual responsibility, he writes, "there is obviously in modern humanity a certain tendency toward... the toleration"76 of a social system in which they share "common responsibility."77

To be sure, Havel's focus is broader than legal theory. But law is certainly encompassed within his vision. For him, strict adherence to an external legal code is-if not immoral-certainly not morally stimulating. ${ }^{78}$ Bettering social life, he stresses, "is a job for people and not for laws and institutions." ${ }^{, 79}$ Rigid adherence to a rule of law, whether a constitutional code of individual rights or democratic legislation, stifles individual responsibility by eliminating the need for it. $^{80}$

Within American legal traditions, individuals need not be responsible for their own actions in the sense that, if the code is followed, the actions are acceptable. Within legal systems, there is no assumption of, or requirement that, individuals display civic virtues, such as compassion for others, in making decisions that affect their community. Civic virtues are not formally discouraged, but by failing to demand and

75. HAVEL, The Power, supra note 74, at 143.

76. Id. at $144-45$ ("In everyone there is some willingness to merge with the anonymous crowd and to flow comfortably along with it down the river of pseudolife."). In Politics and Conscience, Havel wrote that "[m]an rejected his responsibility as a 'subjective illusion'-and in place of it installed what is now proving to be the most dangerous illusion of all: the fiction of objectivity stripped of all that is concretely human." HaVEL, Politics, supra note 74, at 255.

77. Havel, The Power, supra note 74, at 143; see id. at 176 ("This independent life is not separated from the rest of life ('dependent life') by some sharply defined line. Both types frequently co-exist in the same people."). "This professional ruler is an 'innocent' tool of an 'innocent' anonymous power ...." HAVEL, Politics, supra note 74, at 257. Havel then contrasts the responsibility inherent in an individual's idea to create a better world and the irresponsibility of surrendering to an ideology:

[W] hen an idea ceases to express the transcendent dimension of being human and degenerates into a substitute for it, the moment when product, the plan for a better world, ceases to be an expression of man's responsible identity and begins, on the contrary, to expropriate his responsibility and identity, when the abstraction ceases to belong to him and he instead begins to belong to it. VÁClav Havel, Anatomy of a Reticence, in OPEN LETTERS: SElECTED WRITINGS 19651990 at 291, 302 (Paul Wilson ed., 1991).

78. For example, he explains how a legal code "lets individuals fool themselves into thinking they are merely upholding the law and protecting society from criminals," when in fact, they are reinforcing an ideology for which they are not taking individual responsibility. HAVEL, The Power, supra note 74, at 188.

79. Id. at 191.

80. Id. at 191-92. "The key to a humane, dignified, rich and happy life does not lie either in the [C]onstitution or in the Criminal Code." Id. at 191. 
respect them, they fall to the realm of purely private decision. ${ }^{81}$ While individuals may take individual responsibility, the law as understood by traditional American legal theory does not expect or demand it.

By contrast, Havel's vision of law would demand a great deal from individuals. They would be expected to exercise compassion and sympathy for others. As Havel describes the goal: "We [should] not be ashamed" of individual virtues; they should be "free[d] from their 'private' exile and accept[ed] ... as the only genuine starting point of meaningful human community." 82 More specifically with regard to law, Havel rejects the notion that responsible citizens can simply adhere to a preestablished legal code: "These merely establish what may or may not be done and, thus, they can make life easier or more difficult. They limit or permit, they punish, tolerate, or defend, but they can never give life substance or meaning." 33 Havel stressed that law must be viewed "against the background of life as it really is." 84 Without individual responsibility, members of a society "become... satisfied if all the appropriate regulations have been observed." 85 "A reaffirmed human responsibility," he offers, "is the most natural barrier to all irresponsibility." 86

\section{The Necessity of an Individual-Responsibility-Based Theory of Capital Punishment}

A responsibility-based theory of capital punishment is not a variant of

81. Robert Schopp reinterprets modern doctrine in a way that would prohibit sentencers from acting as the responsible agents Havel envisions because Schopp believes that that sort of personal responsibility is inconsistent with the rule of law. Schopp writes:

Authorizing the jury to sentence offenders by appeal to the community conscience understood either as moral principles endorsed by the jury as a sample of the community or as the informal social consensus as understood by the jury would violate the fundamental boundary between the public and nonpublic domains of a liberal society. It would do so by subjecting the offender to sentencing according to standards regarding which he had no notice and no opportunity to participate in establishing.

Schopp, supra note 40, at 516. Schopp is correct in his analysis of American legal theory, but wrong to assume that, in practice, American society actually subscribes to that theory.

82. HAVEL, Politics, supra note 74, at 267.

83. HAVEL, The Power, supra note 74, at 191-92.

84. Id. at 192.

85. Id.

86. HAVEL, Politics, supra note 74, at 268. 
some exotic eastern European legal theory that would require radical restructuring of the way we think about law. ${ }^{87}$ On the contrary, individual responsibility is a necessary component of any justification of a capital punishment system that arises of its own accord from the way that we in fact think about the death penalty. ${ }^{88}$ This section explores the disconnect between American legal theory and our actual beliefs with respect to capital punishment. It concludes that American legal theory highlights or emphasizes certain aspects of our thinking about law-in particular our desire for rational, predictable means of administering justice - and suppresses our desire for someone to take responsibility for grave decisions that dramatically affect the lives of others. The suppression of one aspect of thought and the highlighting of the other is likely a result of the contradictory nature of the two ways of thinking. If the outcome of a legal question is predictable, the decision-maker bears little responsibility for it. But when individuals are responsible, their decisions are not necessarily predictable. Our attachment to both types of decision-making may explain why the Court has adopted doctrine that serves the suppressed goal of individual responsibility better than the goals that the Court has been ostensibly pursuing.

A capital punishment system requires participants to play a role in a project-ending the life of another member of the society-that most of us would find inconceivable outside the system. In our everyday lives, most of us have mechanisms that preclude us from exercising excessive force against others, much less taking their lives. By contrast, Robert

87. Havel himself recognizes that the specific problems he addresses in posttotalitarian socialist society in eastern Europe are not different in basic form from those in western society. HAVEL, The Power, supra note 74, at 207-09.

In a democracy, human beings may enjoy many personal freedoms and securities that are unknown to us, but in the end they do them no good, for they too are ultimately victims of the same automatism, and are incapable of defending their concerns about their own identity or preventing their superficialization or transcending concerns about their own personal survival to become proud and responsible members of the polis, making a genuine contribution to the creation of its destiny.

Id. at 208; see HAVE, Politics, supra note 74, at 263 ("It really is not all that important whether, by accident of domicile, we confront a Western manager or an Eastern bureaucrat in this very modest and yet globally crucial struggle against the momentum of impersonal power."). In particular, he criticizes modern democracies as "founded more on mistrust than mutual confidence, and more on collective irresponsibility than on responsibility." HAvel, The Power, supra note 74, at 210-11.

88. Havel described his conception of individual responsibility by analogizing it to Christianity-"not something partial" or accessible by only a few, but something universal and "potentially accessible to everyone." HAvEL, The Power, supra note 74, at 194-96. "[T] hat arrogant self-projection [of raising the consciousness of the masses] is ... intrinsic to an essentially different way of thinking, the kind that feels it has a patent on some ideal project and therefore that it has the right to impose it on society." Id. at 197. 
Cover has explained that "[p]ersons who act within social organizations that exercise authority [such as criminal sentencing] act violently without experiencing the normal inhibitions or the normal degree of inhibition which regulates the behavior of those who act autonomously." 89 As a practical matter, there is no alternative. If legal punishment is to be inflicted "safely and effectively," Cover argued, "responsibility for the violence must be shared; law must operate as a system of cues and signals to many actors who would otherwise be unwilling, incapable or irresponsible in their violent acts." 90

American legal theory emphasizes the desirable role of law in mediating individual behavior with social systems to procure evenhanded decisions, not influenced by conscious or unconscious prejudices that would likely sway more autonomous decisions. But there are certain decisions that are so intertwined with moral questions that decision-making according to the rule of law is unacceptable. Kent Greenawalt has argued:

There are many fundamental questions of morality that are critical for the appropriate boundaries of legal protection for which rational secular morality cannot provide any single persuasive answer... . [In those cases,] every citizen must resolve [the question] on the basis of some nonrational judgment, a judgment that is not irrational or against reason, but which goes beyond what rationality can establish. ${ }^{91}$

89. Robert M. Cover, Violence and the Word, 95 YALE L.J. 1601, 1615 (1986). Craig Haney has made a similar point:

To ensure its viability, the system of death sentencing in the United States depends on the creation of an extraordinary set of psychological conditions. These conditions must prevail in capital trials to facilitate or somehow "enable" the participation of ordinary people in a potentially deadly course of action. Since, under typical circumstances, a group of twelve law-abiding persons would not calmly, rationally, and seriously discuss the killing of another, or decide that the person in question should die and then take actions to bring about that death, this unique set of conditions is crucial to allow the death-sentencing process to go forward.

Craig Haney, Violence and the Capital Jury: Mechanisms of Moral Disengagement and the Impulse to Condemn to Death, 49 STAN. L. REV. 1447, 1447-48 (1997).

90. Cover, supra note 89 , at 1628 . Those who argue that capital punishment would likely be impossible without mechanisms that insulate the participants from the violence of their decision may be missing this point. See Haney, supra note 89, at 148586. All criminal sentencing would be impossible without legal mechanisms. But those mechanisms are not necessarily bad faith trickery. As Cover makes clear, they are integral to the performance of a social role.

91. Kent Greenawalt, Natural Law and Political Choice: The General Justification Defense-Criteria for Political Action and the Duty to Obey the Law, 36 CATH. U. L. REV. 1, 35 (1986). 
Laura Underkuffler has applied Greenawalt's insights to capital punishment systems, ${ }^{92}$ arguing that individuals experience "conflict between our belief in the rule of law, under whose authority decisionmakers detachedly enforce law made by others," and our need in cases deeply intertwined with moral decisions for "a human being [to] be personally and morally responsible." doctrine may have developed in the way that it has because "the Court instinctively perceives" our social need for individually responsible decision-making even at the expense of "erratic judgments, standardless decisionmaking, and the use of factors that we - as a society-abhor."94

Greenawalt and Underkuffler see individual responsibility as a necessary element in legal decisions with serious moral underpinnings. But they view this necessary responsibility as compromising American ideals. 95 The law, they contend, generally and desirably employs "rational processes" to reach an ex ante reproducible result that is supported by a social consensus. ${ }^{96}$ Introducing individual responsibility necessarily detracts from that process. Just as some of the justices and commentators see modern capital punishment doctrine as a zero sum

92. See generally Laura S. Underkuffler, Agentic and Conscientic Decisions in Law: Death and Other Cases, 74 Notre DAME L. REV. 1713 (1999). While Underkuffler was concerned with capital punishment, there is at least some reason to believe that all criminal sentencing is subject to the same conflicts between our commitment to both a rule of law and to individual responsibility for morally significant decisions. See Payne v. Tennessee, 501 U.S. 808, 821 (1991) (commenting that criminal sentencing in the federal system had not historically been guided by the rule of law-"a judge may appropriately conduct an inquiry broad in scope, largely unlimited either as to the kind of information he may consider, or the source from which it may come").

93. Underkuffler, supra note 92 , at 1735 . See Eisenberg et al., supra note 51 , in which the authors conclude:

The moral quality of the capital sentencing decision depends on the sentencer believing she is responsible for the sentence. A sentencer who believes she alone bears responsibility for the defendant's fate will attend to her task with the requisite degree of moral seriousness, and a decision made without such seriousness is less reliable. If a sentencer believes, or has been led to believe, that she does not bear full responsibility, either because she can defer to another actor's prior decision or can delegate her sentencing authority to a subsequent actor in the process, then the reliability of the sentencer's decision is for that reason suspect. In our terminology, Caldwell insists that jurors understand and accept the role the law assigns them as capital sentencers. Id. at $342-43$.

94. Underkuffler, supra note 92 , at 1735 \& n.95 ("[J]uries may nullify for bad reasons as well as good, and no one has yet thought of a formula that would produce nullification only in deserving cases." (quoting Kent Greenawalt, Conflicts of Law and Morality-Institutions of Amelioration, 67 VA. L. REv. 177, 230 (1981))).

95. See generally Underkuffler, supra note 92, at 1713; Greenawalt, supra note 91, at 1. "With personal [autonomous, individually responsible] decision-making comes the danger of arbitrariness, the use of prohibited factors, and the violation of the very values that the law (as a consensual matter) has established." Underkuffler, supra note 92, at 1719.

96. Id. at 1720 . 
tradeoff between individualization and consistency, Greenawalt and Underkuffler appear to see a similar tradeoff between the morality of responsibility and the morality of evenhanded decision-making.

Havel's individual-responsibility-driven social theory, by contrast, posits individually responsible decision-making, not as a necessary evil, but as a positive force for constructing a society's moral foundation. His vision, if extended to a capital punishment system, would require participants to engage both the defendant as a person and the values of the community in which the crime was committed. They would have to embrace, not just the circumstances of this crime, but also the defendant's character, past experience, and place in the community. ${ }^{97}$ This process of engagement is central to each participant's role as a responsible citizen participating in an important social function. Their capacity to empathize with the defendant while understanding their community does not hinder reasoned decision-making or grant prejudices free play. On the contrary, it is enabling. Without empathy and understanding, there cannot be an engaged moral decision, and participants in the process would be little more than calculatorsweighing legal interests-with much less of a real stake in the decision. ${ }^{98}$

Under Havel's approach, individual responsibility does not require us to compromise our commitment to rational decision-making. It simply keeps the scale from tipping too far toward the unexamined exercise of social violence. Cover correctly points out that law must displace, to some extent, the mechanisms that keep us from acting violently outside of legal systems if the system is to function. Embracing individual responsibility within the system does not transform the experience of criminal sentencing into the experience of actually treating another violently. It does serve as a necessarily minimal reminder or assurance that the participants understand that violence is indeed being done.

97. Cf. Pillsbury, supra note 40 , at 670,677 (explaining that a proper evaluation of desert requires access to the sentencer's emotions, and that law generally assumes that individuals are responsible for how their emotions affect their decisions in contrast to the popular psychological view that emotions are events that simply happen to us and for which we have no responsibility).

98. SCHAUER, supra note 46 , at 145 ("[W] hen there are simply no rules to consult, the conscientious decision-maker looks at each decision-prompting event in as much relevant detail as the event offers."); West, supra note 51, at 91. 


\section{Modern Capital Punishment Doctrine and Responsibility Theory}

This subsection summarizes the Court's overly optimistic approach to responsibility and the commentators' overly skeptical view. It then describes how modern doctrine in fact heightens responsibility compared to pre-Furman doctrine. In particular, it shows how different aspects of the doctrine work to broaden the responsibility of different actors in the process, and it explains that complete discretion does not maximize responsibility because of the individual tendency to side step that responsibility. The appropriate role of doctrine is to create an environment in which discretionary decisions are worthy of trust. By combining structure and discretion, modern doctrine has taken a step in the right direction, however far it may remain from being a morally acceptable system.

\section{The Supreme Court's Discussion of Individual Responsibility}

The Supreme Court has had remarkably little to say about individual responsibility throughout the course of its doctrine-making cases. Justice Harlan's opinion in McGautha exhibited almost an absolute confidence in the ability of a sentencing jury to take individual responsibility for its decision.

The States are entitled to assume that jurors confronted with the truly awesome responsibility of decreeing death for a fellow human will act with due regard for the consequences of their decision and will consider a variety of factors, many of which will have been suggested by the evidence or by the arguments of defense counsel. ${ }^{99}$

Because no list of factors could ever be complete, any attempt to catalog them would inhibit the juror's ability to exercise their individual responsibility. And, given the "infinite variety of cases and facets to each case," Harlan wrote, general guidelines would amount to "either meaningless 'boiler-plate' or a statement of the obvious that no jury would need." 100

While Harlan was correct to see the necessity of individual responsibility in capital sentencing, he failed to appreciate two important factors. First, capital sentencing involves numerous participants who should share responsibility. Even if discretionary jury sentencing of the type then employed fully tapped the responsibility of individual jurors, it did virtually nothing to ensure that other actors in the processparticularly legislators, prosecutors, and appellate courts-took

99. McGautha v. California, 402 U.S. 183, 207-08 (1971).

100. Id. at 208. 
individual responsibility for their roles. Second, the pre-Furman structure was actually unlikely to tap juror responsibility because of the tendency of individuals to deflect that burden. Law can be a device to focus responsibility, but as Justice Brennan pointed out in his McGautha dissent, pre-Furman law was "purposely constructed to allow the maximum possible variation from one case to the next."101 To be sure, Brennan may have been thinking about using rules to directly guide the jury's decision, rather than to heighten the jury's sense of responsibility and thereby better calibrate the juror's internal moral compass. But preFurman law did neither.

In its long series of post-McGautha, doctrine-building cases, the Court has said virtually nothing about individual responsibility. The one exception is Caldwell v. Mississippi ${ }^{102}$ in which the Court declared that its doctrine had "taken as a given that capital sentencers would view their task as the serious one of determining whether a specific human being should die at the hands of the State." 103 Justice Marshall explained for the Court:

Belief in the truth of the assumption that sentencers treat their power to
determine the appropriateness of death as an "awesome responsibility" has
allowed this Court to view sentencer discretion as consistent with-and indeed
as indispensable to-the Eighth Amendment's "need for reliability in the
determination that death is the appropriate punishment...."104

By connecting sentencer discretion and responsibility with its own conception of reliability, Caldwell suggests that the Court may, at least momentarily, have understood the role of individual responsibility as Havel did: A responsible sentencing decision is-because it is responsible - an appropriate sentencing decision. There is no external measuring rod. The scale is the heart of the decision-maker.

But even in Caldwell, the Court appeared to see the role of law as merely ensuring that individual jurors were not led astray by improper argument or instructions. As in McGautha, there is no sense of the possibility that law could work to heighten the responsibility of all actors in the system or that law was needed to aid jurors in focusing their responsibility in every case, not just in those where a prosecutor or trial judge said something improper.

101. Id. at 248 .

102. 472 U.S. 320 (1985).

103. Id. at 329.

104. Id. at 329-30 (quoting Woodson v. North Carolina, 428 U.S. 280, 305 (1976)). 
In any event, Caldwell is a lone voice in the wind. In numerous cases, the Court has stressed the role of modern doctrine in directly dictating the outcome of capital sentencing decisions in precisely the ways that would tend to reduce a juror's sense of responsibility. ${ }^{105}$ Caldwell itself has been interpreted quite narrowly to prohibit only inaccurate statements that tend to lessen the jury's sense of responsibility. ${ }^{106}$ This emphasis on improving the accuracy of the inputs, rather than freeing the minds of the jurors from devices that would deflect their sense of responsibility, suggests that the Court now sees Caldwell very differently than did the original Caldwell majority. By stressing that discretion was essential to reliability, Justice Marshall's majority opinion in Caldwell appreciated the juror as an empathetic human being capable of making a morally acceptable sentencing decision. The Court's later emphasis on accuracy harkens instead to a sentencer engaged in a mechanical calculus where we need only ensure that the correct inputs are plugged into the calculator. ${ }^{107}$

105. See, e.g, Johnson v. Texas, 509 U.S. 350, 362 (1993) ("States are free to structure and shape consideration of mitigating evidence 'in an effort to achieve a more rational and equitable administration of the death penalty."' (quoting Boyde v. California, 494 U.S. 370, 377 (1990))); Saffle v. Parks, 494 U.S. 484, 493 (1990) ("It would be very difficult to reconcile a rule allowing the fate of a defendant to turn on the vagaries of particular jurors' emotional sensitivities with our longstanding recognition that, above all, capital sentencing must be reliable, accurate, and nonarbitrary."); Blystone v. Pennsylvania, 494 U.S. 299, 309 (1990) (holding that a state may require the sentencer to impose a death sentence where aggravating evidence outweighs mitigating evidence); Franklin v. Lynaugh, 487 U.S. 164, 179 (1988) (plurality) ("Given the awesome power that a sentencing jury must exercise in a capital case, it may be advisable for a State to provide the jury with some framework for discharging these responsibilities.").

106. Justice O'Connor stressed in a concurring opinion the important-to her mind-fact that the prosecutor had misled the jury to believe that the Mississippi appellate court had more discretion to review a death sentence than it actually had. Caldwell, 472 U.S. at 342 . Where the plurality suggested that any statement about appellate review would be problematic, she stressed that an accurate instruction on the role of appellate courts would not. Id. In Romano v. Oklahoma, a five to four majority held that introducing evidence that the defendant had been sentenced to death in another case did not violate Caldwell. 512 U.S. 1 (1994). Whether it lessened the juror's individual responsibility was irrelevant because the information was accurate at the time it was presented to the jury. Id. In a concurring opinion, Justice O'Connor wrote that "[t]he inaccuracy of the prosecutor's argument in Caldwell was essential to [her] conclusion that the argument was unconstitutional.... An accurate description of the jury's role —even one that lessened the jury's sense of responsibility-would have been constitutional." Id. at 14; see also Sawyer v. Smith, 497 U.S. 227, 258 (1990) (holding that Caldwell error is not sufficiently fundamental to justify retroactive application); Dugger v. Adams, 489 U.S. 401, 408-10 (1989) (refusing to apply Caldwell where defendant failed to object on state law grounds in a pre-Caldwell case).

107. Even the initial interpretation of Caldwell has been criticized for assuming that jurors will accept an appropriate level of responsibility unless they are misguided by the prosecutor or the court. In fact, jurors may seek out ways to avoid responsibility unless they are affirmatively told that they must bear it. See Hoffman, supra note 70, at 1138. 


\section{Academic Analysis of Modern Doctrine in Terms of Individual Responsibility}

To the extent that commentators have written about individual responsibility in capital sentencing, they have focused almost exclusively on the ultimate sentencer, usually the jury, and they have assumed that there is an inverse relationship between the degree of rationality or guidance in the process and the degree of sentencer responsibility. For these commentators, individual sentencer responsibility was at its zenith in the pre-Furman period, and any movement towards a more reasoned sentencing process in the postFurman statutes necessarily lessens jury responsibility. ${ }^{108}$ They see legal guidance as a crutch on which sentencers may lean to avoid directly facing the decision for which they should take individual responsibility. For example, a juror might seek to escape the moral burden by reasoning: "I did not decide that a death sentence was appropriate here; under the law, I had no choice."

These commentators typically ignore modern doctrine's individualized sentencing requirements because, by definition, that doctrine is more legalistic in form than pre-Furman practice. That very form enables a sentencer to displace individual responsibility by deferring to the law.

Modern doctrine, however, recognizes that either clear, strict rules or absolute, unfettered discretion would leave too much leeway for actors in the process to lessen their sense of responsibility. If the system is too rule-like, decision-makers can hide behind the law. ${ }^{109}$ If the system is

108. For example, Professor Hoffmann questioned whether modern Eighth Amendment doctrine should be reconsidered because it might be impossible

to give a "little" guidance... without the jurors mistakenly concluding that they are getting a "lot" of guidance, and thus avoiding their personal moral responsibility for the sentencing decision[.]

... Perhaps our attempts to create "rationality" from within, by drafting lists

of "aggravators" and "mitigators," merely permit the jury to conclude that there is a legally "correct" answer to the sentencing question.

Hoffmann, supra note 70 , at 1159 . Professor Sherman similarly contends that "the setting of rules and guidelines... may have an additional (and perhaps unintended) effect on the degree of responsibility experienced by the jurors.... The clearer the guided discretion, the more likely it is that jurors can place responsibility for their sentencing decision on the law and its requirements." Sherman, supra note 50, at 1244; see Weisberg, supra note 39, at 391-95.

109. SCHAUER, supra note 46 , at $145-46$.

[W] hen a decision-maker decides according to rules and therefore relies on decisions made by others, she is partially freed from the responsibility of 
too open-ended, decision-makers can divert responsibility with rules of thumb of their own making. Religious and social practice provide an array of rationalizations to which a sentencer could turn for help in making the difficult sentencing choice. At a loss for guidance, the logic of an eye-for-an-eye may have powerful appeal. ${ }^{110}$ Both types of systems would enable actors throughout the process to take the easy way out and escape the strain of an individually responsible decision.

\section{The Ways in Which Modern Doctrine Fosters Responsibility}

Compared to pre-Furman practice, modern doctrine heightens the sense of responsibility of participants at each level in the sentencing process-legislator, prosecutor, sentencer (jury or judge), and appellate court. The degree of responsibility may remain less, perhaps far less, than optimal, but it is better. Part IV of this Article addresses the additional benefits that could be obtained by explicitly focusing on individual responsibility as the goal of capital punishment doctrine.

\section{a. The Legislator's Responsibility}

Before Furman, the individual legislator had virtually no responsibility at all. A statute declared murder-and perhaps rape-to be crimes potentially punishable by death. But murder and rape themselves were defined by the most uncertain concepts in criminal law-malice, premeditation, and consent-and the death penalty was simply available for all, but rarely imposed on any, murderers and rapists. ${ }^{11}$ As a result, any individual legislator could disclaim responsibility for the death penalty simply by focusing on the absolute discretion placed in the hands of the jury. ${ }^{112}$

scrutinizing every substantively relevant feature of the event.... [W] hen a decision-maker follows a rule she no longer examines every facet of the decision-prompting event with the same degree of care she would have employed had there been no rules.... At times a rule removes so many factors from consideration that a decision-maker may relax almost completely, Id. making decisions that require virtually no effort whatsoever.

110. A Gallup Poll released on March 2, 2001, indicated that nearly half of those who supported the death penalty gave "an eye for an eye" as the basis for their belief. The Gallup Organization, Death Penalty: Why Do You Favor the Death Penalty for Persons Convicted of Murder?, at http://www.gallup.com/poll/indicators/ inddeath_pen. asp (last visited Mar. 19, 2001); see William J. Bowers, The Capital Jury Project: Rationale, Design, and Preview of Early Findings, 70 IND. L.J. 1043, 1072 (1995) (discussing how jurors who lack understanding of their role tend to resort to familiar concepts to define the basis for their decision).

111. Furman v. Georgia, 408 U.S. 238, 311 (1972) (White, J., concurring).

112. Justice White's concurrence in Furman rested at least in part on the 
Today, state legislatures must enact a carefully crafted law that requires the prosecution to prove something beyond murder before the defendant will be eligible for the death penalty. That something may involve aggravating factors about the crime (for example, the victim was a police officer) or the defendant's character (a history of prior violent felony convictions for instance). To be sure, a legislature can draft a death penalty statute with a list of aggravating factors that is sufficiently extensive to cover a very high percentage of murders. But an individual legislator must consider whether each circumstance chosen is sufficiently egregious to distinguish a defendant who fits the category from a generic murderer who does not. Forcing the legislator to face the question, "Does a defendant to whom this particular circumstance applies potentially deserve to die," meaningfully ratchets up the level of responsibility that must be taken by legislators supporting a capital sentencing law when compared to the pre-Furman process.

\section{b. The Prosecutor's Responsibility}

Like the legislator, the pre-Furman prosecutor had little to think about. The defendant was prosecuted for murder or rape. While the prosecutor was free subtly to persuade or dissuade the jury from imposing a death sentence, nothing in the law required that prosecutor to take any stance whatsoever. Like the legislator, the prosecutor could leave all responsibility to the jury. A prosecutor might have taken adequate responsibility-and surely many did-but pre-Furman doctrine did not require or encourage that sort of responsible behavior. It was purely a matter of individual choice.

Under the post-Furman regime, prosecutors in many jurisdictions must select the aggravating circumstances on which to rely in a separate sentencing proceeding. Additionally, in all jurisdictions, the prosecutor must stand before the sentencer and say that this defendant is distinguished from others by specific aggravating criteria that make death an appropriate punishment, not just that the defendant committed murder. To be sure, the legislature has chosen that criteria, but the prosecutor cannot escape responsibility for at least two reasons. First,

legislature's lack of responsibility for death sentences that were imposed. Id. at 314 ('Legislative 'policy' is thus necessarily defined not by what is legislatively authorized but by what juries and judges do in exercising the discretion so regularly conferred upon them."). 
many of the aggravating circumstances do not involve black and white issues. The prosecutor thus bears responsibility for (1) deciding whether to rely on them, and (2) convincing the jury that they apply. Second, given the doctrine permitting the defendant to introduce mitigating evidence, the prosecutor must go beyond merely proving the aggravating factors chosen by the legislature and must explain why, despite the proffered mitigating evidence, death is appropriate.

Modern doctrine grants significant discretion to the prosecutor. But that discretion is appropriate because it ensures that the prosecutor faces a choice for which individual responsibility must be taken. Requiring the prosecutor to make that grave choice in a way that Furman's prosecutor could avoid is an important way in which modern doctrine heightens responsibility. ${ }^{114}$

\section{c. The Sentencer's (Jury's or Trial Judge's) Responsibility}

Unlike the legislator and prosecutor, who have been all but completely ignored by those who have thought about the importance of responsibility in capital sentencing, there has been serious discussion of the level of responsibility assumed by the sentencer, at least when a jury

113. Statistical analysis supports the conclusion that prosecutors exercise significant discretion in determining cases in which the death penalty will be sought. For example, prosecutors in different cities operating under the same state law often have vastly different practices and records in capital cases. Stephen B. Bright, Will the Death Penalty Remain Alive in the Twenty-First Century?: International Norms, Discrimination, Arbitrariness, and the Risk of Executing the Innocent, 2001 WIS. L. REV. 1, 15-16 (relating the example that Houston district attorneys seek and obtain far more death sentences than Dallas district attorneys, even though Dallas has a higher murder rate); see LIFTON \& MiTCHELL, supra note 6, at 4 ("Even within the same state, procedures for prosecuting capital cases vary from county to county.").

114. James Liebman's important and recent article identifies a disturbing incentive structure for prosecutors that tends to encourage them to pursue death sentences for political purposes without sufficient regard for whether the sentence is appropriate. Liebman, supra note 4, at 2100-01. His argument, however, does not undermine the contention made here that prosecutors have more individual responsibility under modern doctrine than they did pre-Furman. Moreover, he correctly identifies the appropriate solution as procedural requirements designed to better focus and clarify the prosecutor's individual responsibility rather than a wooden checklist that would blunt prosecutorial discretion by blinding them to the uniqueness of particular cases.

The prosecutor must wait 120 days after indictment before announcing a decision to prosecute the case capitally, at which time the lead prosecutor on any case charged capitally must file a report with the district attorney, the state attorney general, and the defense, justifying the capital charge. The report must identify the facts making the offense death-eligible under state and federal constitutional law, the aggravating circumstances to which the state will be limited at trial, the reasons why the level of aggravation net of mitigation warrants a death sentence, and the evidence warranting nearcertainty on each of those points.

Id. at $2144-45$. 
does the sentencing. As described above, this analysis tends to emphasize how much responsibility was placed in the hands of the juror pre-Furman. For example, pre-Furman jury instructions often stressed that "whether you recommend or withhold mercy is a matter solely within your discretion." Also, jurors were often told not to be guided by sympathy or other factors that might serve "as a means of escaping a hard or disagreeable duty."

While the unguided discretion fostered by instructions of this type may theoretically maximize the sentencer's responsibility, it also leaves the sentencer wholly unfettered in its ability to belittle the responsibility it has. For example, a juror could easily rely on the lex talionis and say: "this man committed murder, he deserves to die."117 And this responsibility-escaping potential is not one-sided. A juror might similarly reason something like: "Jesus preached forgiveness so I will vote for life." 118 In both examples, responsibility could be transferred from the individual juror to the Bible without violating the jury's instructions. ${ }^{119}$

No doubt, some jurors took their roles seriously in the pre-Furman era. But many probably did not. The psychological literature indicates that individuals faced with grave decisions will (1) look for ways to escape responsibility, and (2) revert to ingrained decision-making forms when they are uncertain of the rules they should follow. ${ }^{120}$ Those

115. State v. Caldwell, 21 N.E.2d 343, 344 (Ohio 1939); see People v. Friend, 306 P.2d 463, 474 (Cal. 1957) ("[T] he law does not itself prescribe, nor authorize the court to innovate, any rule circumscribing the exercise of their discretion, but, rather, commits the whole matter of its exercise to the judgment and the consciences of the jury ....”).

116. Caldwell, 21 N.E.2d at 344.

117. Exodus 21:23-25 ("[T] hou shalt give life for life, [e]ye for eye, tooth for tooth, hand for hand, foot for foot, [b]urning for burning, wound for wound, stripe for stripe.").

118. Matthew 5:38-39 "'Ye have heard that it hath been said, [a]n eye for an eye, and a tooth for a tooth: But I say unto you, [t]hat ye resist not evil: but whosoever shall smite thee on thy right cheek, turn on him the other also.").

119. While religion does not provide the only means for side-stepping individual responsibility, it is a particularly common example as evidenced by the regular use of religious analogy by both prosecuting and defense attorneys arguing capital cases. John H. Blume \& Sheri Lynn Johnson, Don't Take His Eye, Don't Take His Tooth, and Don't Cast the First Stone: Limiting Religious Arguments in Capital Cases, 9 WM. \& MARY BILL RTS. J. 61, 64-74 (2000) (cataloging religious analogies employed by prosecutors and defense counsel in capital cases).

120. See Bowers, supra note 110, at 1072 \& nn.159-60; Peter Meijes Tiersma, Dictionaries and Death: Do Capital Jurors Understand Mitigation?, 1995 UTAH L. REV. 1,12 ("[E]vidence, supported by common sense, [indicates] that when jurors do not understand instructions, they simply rely on their own rough notions of justice."); supra 
findings strongly suggest that most jurors probably did not accept the responsibility that pre-Furman doctrine purported to give them.

Just as commentators addressing responsibility in capital sentencing tend to romanticize the level of responsibility accepted by the unfettered juror, they tend to demonize modern doctrine for providing guidance. Commentators fear that the legalistic process now governing both the findings necessary to make a defendant eligible for the death penalty and the weighing of aggravating and mitigating factors enables jurors to pass responsibility to the legislature for the ultimate sentencing decision. The legislature put the sentencing scheme in place, this argument runs, and must take responsibility for its outcome. The sentencer's job is merely to apply the rules adopted by someone else. ${ }^{121}$

While this interpretation of the effect of modern doctrine is plausible as far as it goes, it provides too narrow an account. The death eligibility finding under modern doctrine is, to be sure, a legalistic enterprise, but no more so than the finding that the defendant was guilty of murder in the pre-Furman era. Under both types of regimes, sentencers were required to make certain structured findings before considering whether the defendant should die. Whatever impact adding this second legalistic exercise might have on sentencer responsibility, however, is entirely undone by the other aspect of modern doctrine that mandates a separate sentencing trial at which mitigating evidence is presented. ${ }^{122}$

As an initial matter, the mere existence of the separate trial to consider the sentence helps undermine the simplest defense mechanism that a sentencer may employ: the rule of thumb that all murderers deserve to be executed. Pre-Furman law-at least in states without separate sentencing proceedings-permitted that sort of simplistic reasoning. Modern doctrine does not. Jurors surely must understand that if murder alone were enough to render a defendant deserving of death, there would be little need for an entirely separate proceeding.

Second, and more important, modern doctrine requires that the sentencer consider, and be permitted to give effect to, all evidence offered by the defendant that might serve as a basis for a sentence less than death. ${ }^{123}$ An unfettered juror could, without violating the oath,

notes 50-57 and accompanying text.

121. See Weisberg, supra note 39, at 376-79. "The formal, legalistic image of the law of capital punishment that the jury now receives from the court and the prosecutor is often a great advantage to the state." Id at 383; see also Pillsbury, supra note 40, at 667.

122. The benefit of a legalistic death-eligibility finding is that it heightens the level of responsibility that must now be accepted by the legislator. See supra Part III.D.3.a.

123. Pillsbury, supra note 40 , at 658 (recognizing that the "Supreme Court has made significant efforts to protect the [juror's] opportunity to empathize in its capital jurisprudence, but has failed to see the need to affirmatively encourage sentencer empathy"). 
ignore the defendant's character, background, and even role in the crime and rely instead on a socially- or religiously-driven rule of thumb that murder justifies a death sentence. Where there are no standards, there are no roadblocks preventing the free play of psychological defense mechanisms that enable us to avoid difficult decisions. Modern doctrine closes that door by commanding that the sentencer consider each and every mitigating circumstance and then decide-with full power to give effect to the mitigating evidence-whether the death penalty is appropriate. The buck stops there. A finding of murder, or even sufficient aggravating circumstances to make the defendant deatheligible-two decisions for which responsibility could be passed to the legislature-are simply not enough. While not eliminating a sentencer's ability to belittle its own responsibility by employing rules of thumb, modern doctrine goes to great lengths to discourage the juror from doing so. ${ }^{124}$

\section{d. The Reviewing Court's Responsibility}

Commentators and the Court have recognized the possibility that appellate review may undermine the sentencer's sense of responsibility. ${ }^{125}$ There has been little discussion, however, of the extent to which appellate court judges bear individual responsibility for death

124. All this is not to say that, as a practical matter, sentencers today necessarily accept a greater degree of responsibility for their decisions than they did in the preFurman era. By the 1950 s, some states employed separate sentencing proceedings and some trial judges permitted defendants to introduce mitigating evidence, even at the guilt phase, that would not be appropriate in noncapital cases. By contrast, today's sentencing juries are instructed in a variety of ways that may overemphasize the legalistic aspects of modern doctrine and confuse, if not ignore, the responsibility-enhancing aspects of modern doctrine. The Court has been at best inconsistent in its enforcement of its own doctrine. Compare Penry v. Johnson, 121 S. Ct. 1910, 1920-24 (2001) (striking down a death sentence where the instructions likely confused the jury about its ability to give effect to mitigating evidence) with Buchanan v. Angelone, 522 U.S. 269, 279 (1998) (upholding a death sentence despite the absence of instruction on how the jury could give effect to mitigating evidence). This shortcoming, however, arises from the inappropriate goals that the Court continues to pursue rather than the structure of the doctrine itself. States struggling to apply capital sentencing systems that are both fully consistent and fully individuating not surprisingly give short shrift to the aspects of doctrine that empower sentencers to give effect to mitigating evidence without meaningful guidance from the legislature. The Court's own inconsistent enforcement efforts are also likely confounded by its mistaken pursuit of meaningless goals. A proper focus on heightening individual responsibility as the goal of modern doctrine would dramatically improve the application of that doctrine. See infra Part IV.

125. See supra Part III.D.1-2. 
sentences.

In the pre-Furman era, appellate courts played no role whatsoever in capital sentencing decisions. Juries had complete discretion and were not subject to any form of appellate review.

Modern doctrine, by contrast, has emphasized the importance of appellate review. While the Court has not imposed a generally applicable standard of review in capital cases, it has suggested that some form of meaningful review is required. ${ }^{126}$ In addition, the Court has demanded careful review when state appellate courts seek to save death sentences where the trial-level sentencer's decision is tainted by error. The state court must either reweigh the aggravating and mitigating evidence for itself, or apply a rigorous beyond-a-reasonable-doubt test to determine whether the error was harmless. The Court has rejected simplistic devices that might enable an appellate court to affirm death sentences without taking sufficient responsibility for the result. For example, the Court prohibited a state court from automatically affirming a capital sentence whenever the defendant was eligible for the death penalty. ${ }^{127}$

\section{E. Evaluating the Empirical Critique of Responsibility Theory}

Independent researchers have interviewed small numbers of capital jurors, and the Capital Jury Project coordinated a multistate effort to interview 80 to 120 jurors from each of fourteen death penalty states. The interviewed jurors in the latter project were about equally divided between juries returning death sentences and life sentences. ${ }^{128}$ While

126. See infra Part IV.B.1.

127. Clemons v. Mississippi, 494 U.S. 738, 752 (1990). An additional part of the capital sentencing process, clemency procedures, has been relatively unaffected by modern capital sentencing doctrine. But even here, there has been some change for the better. Before Furman, the clemency procedure was generally unregulated. While that is still largely true, the Court has indicated that some due process safeguards must be applied to clemency procedures. Ohio Adult Parole Auth. v. Woodard, 523 U.S. 272, 289 (1998) (O'Connor, J., concurring) (stating the opinion of four justices that "some minimal procedural safeguards apply to clemency proceedings"); id. at 290 (Stevens, J., concurring in part and dissenting in part) (agreeing that due process applies to clemency proceedings); see Ford v. Wainwright, 477 U.S. 399, 416-18 (1986) (establishing that clemency procedures are required where a death row inmate claims that his execution should be barred because he is insane). If a death row inmate is insane, due process requires that he have the right to demonstrate that fact. Ford, 477 U.S. at 416-18. A governor is also likely to be required to hear evidence suggesting that an execution would be morally wrong, and take account of it, before denying clemency. By requiring the governor to provide some process, the clemency process too has become a more responsible one.

128. Bowers, supra note 110, at 1043; id. at 1073 (describing earlier independent studies in California, Florida, and Oregon); Eisenberg et al., supra note 51, at 350 (drawing on data from South Carolina juries); Hoffmann, supra note 70 , at 1138 
data of this type is inherently difficult to interpret, on the whole it supports two general conclusions: (1) jurors tend to misunderstand capital sentencing instructions particularly in the areas where the instructions diverge from the jurors' expectations; and (2) while jurors seek ways to lessen their responsibility, modern doctrine works against that tendency and may help-albeit marginally at present-to foster individual responsibility among jurors. ${ }^{129}$ These findings confirm work from various disciplines showing that when jurors are uncertain about their task, they revert to concepts that they understand-such as the beyond-a-reasonable-doubt standard and unanimity. ${ }^{130}$

The Capital Jury Project interviews suggest that a minority of jurors assume, for example, that they are required to impose a death sentence if certain aggravating circumstances are proven (just as they are required to find the defendant guilty if certain facts are proven). ${ }^{131}$ The interviews also suggest that jurors tend to misunderstand unusual aspects of the capital sentencing process-particularly the role of mitigating evidence-that differ markedly from the decision process at the guilt phase. $^{132}$

Several commentators have interpreted the Capital Jury Project data as confirming their fear that modern doctrine "allay[s] jurors' sense of responsibility for their life or death sentencing decisions by appearing to

(drawing on data from Indiana juries); James Luginbuhl \& Julie Howe, Discretion in Capital Sentencing Instructions: Guided or Misguided?, 70 IND. L.J. 1161, 1161 (1995) (drawing on data from North Carolina juries).

129. A pre-Capital Jury Project study indicated that sentencing schemes in states like Texas and Oregon-where jurors are asked to answer a short list of questions, rather than weigh circumstances-may contribute to reducing the jurors sense of responsibility. For example, one juror commented: "We are not sentencing him to death-we are just answering these questions." Bowers, supra note 110, at 1076. But these sorts of statutes actually violate modern doctrine to the extent that they do not require full and careful consideration of mitigating evidence and a reasonable means to give effect to that evidence. The Court recently reiterated this point. Penry, $121 \mathrm{~S}$. Ct. at 1920-21.

130. Bowers, supra note 110, at 1072 \& n.159 ("Uncertainty about how to proceed may cause jurors to 'invent' their own rules or understandings about how the sentencing task should be performed.").

131. Although "a substantial majority of jurors did not believe that the law required a death sentence even if they believed the evidence proved heinousness or dangerousness," the data shows that "[n]early one-third of the jurors were under the mistaken impression that the law required a death sentence if they found heinousness or dangerousness, a result replicated in a multi-state study of the interview data." Eisenberg et al., supra note 51, at 360; see Bowers, supra note 110, at 1091; Luginbuhl \& Howe, supra note 128, at 1173-75.

132. Luginbuhl \& Howe, supra note 128 , at 1165-71. 
provide them with an authoritative formula that yields the 'correct' or 'required' punishment." "133 But the results are far from clear.

Commentators note, with some alarm, that jurors express discomfort with their responsibility. ${ }^{134}$ Those responses, however, could just as easily be viewed positively: they confirm that jurors do sense that an immense responsibility rests with them. The more important issue is whether modern doctrine helps or hinders the jurors in their effort to avoid responsibility. To answer that question, commentators point to a high percentage of jurors who reported that the defendant or the lawrather than the jury or individual jurors - were most responsible for the death sentence. ${ }^{135}$ While it is conceivable that these jurors were seeking to reduce their own responsibility, the answers more likely indicate that the jurors recognized that a death sentence should be imposed only where the defendant deserves it, and that capital sentencing is part of the legal system and would not exist outside of the law. These are correct and unavoidable assumptions that likely have little bearing on the jurors' actual feelings of responsibility for their decision. ${ }^{136}$

Lawyers tend to think of responsibility as we think of water in a bucket. If we assign some responsibility to one person (just as if we ladle out some water), we necessarily have less responsibility (water) to assign someone else. This way of thinking about responsibility is atypical. Responsibility usually connects an individual to a decision or action. That attribution need not be affected in any way by another individual's connection to the same decision or action. ${ }^{137}$ A defendant, the law, and the juror may thus all be responsible for a death sentence.

133. Bowers, supra note 110 , at 1093.

134. Hoffmann, supra. note 70, at $1142-43$. "The jurors overall did not want to be responsible for making the decision of the death penalty." Id. at 1142 . The jurors "had a problem with being responsible for giving that verdict;" one juror prayed for guidance to "tell me what to do, because ... I remember not feelin' sure if I could do it." Id. at 1143.

135. Bowers, supra note 110 , at 1094 (stating that eighty percent of jurors responded "that the defendant or the law [was] most responsible...."); Eisenberg et al., supra note 51, at 354-58. Others have speculated that the relatively low number of executions may lessen the jurors' sense of responsibility. Id. at 352 ("[J]urors' knowledge that executions occur infrequently may unavoidably diminish their sense of causal responsibility."). Of course, the number of executions has increased dramatically in recent years. LIFTON \& MrTCHELL, supra note 6, at xi ("More inmates were executed in our country in 1999 than in any year since 1952, and the execution rate has soared 800 percent in the past decade.").

136. Valerie P. Hans, How Juries Decide Death: The Contributions of the Capital Jury Project, 70 IND. L.J. 1233, 1237 (1995); Eisenberg et al., supra note 51, at 352 (distinguishing the concept of "role responsibility" from "causal responsibility").

137. Robin West, Narrative, Responsibility and Death: A Comment on the Death Penalty Cases from the 1989 Term, 1 MD. J. CONTEMP. LEGAL IsSUES 161, 177 (1990) (explaining how recognizing social responsibility for war crimes or violent criminal behavior "would diminish the responsibility ... not one bit" of the particular criminals who committed the acts). 
Another question from the Capital Jury Project interviews focused on the jury's responsibility vis-à-vis the judge and appellate courts. In response to this question, more than half of the jurors answered that they were solely or mostly responsible. ${ }^{138}$ And, most jurors report that they did not simply count up factors and weigh them in a mechanical way. ${ }^{139}$ Perhaps even more telling are the narrative answers of jurors suggesting that the doctrine reinforced, or at least did not detract from, their inherent understanding that they were responsible. ${ }^{140}$ As three commentators on the Capital Jury Project data concluded: "The 'average' juror is not the juror the Milgram model would lead us to

138. Bowers, supra note 110, at 1096; Eisenberg et al., supra note 51, at 354-58.

139. Eisenberg et al., supra note 51, at 366.

140. Hoffmann, supra note 70, at 1143. Examples of juror statements include: (1) "[W]e all knew that that was a big responsibility"; (2) "[W]e ... were allowing ourselves the right to make that [life or death] decision, and that each of us had that right, you know, and that responsibility"; and (3) "Nothing came close to this, the feeling of the responsibility ...." Id. Another juror explained:

I told [the other jurors], "Put the kid in the chair. Now would you go up there [and] throw the switch yourself?" They said, "Well that's not my job." I said, "You are doing your job now. If you say go ahead, that's the same as [if] you are doing it. Before you do this, make sure that you can sleep tonight or next week or the rest of your life with what you've done."

Id. at 1146. Another juror reported: "I don't think I was aware of a conscious fear of not applying the law correctly. I think I was more aware of just doing the right-what I thought, in my heart, was the right thing to do." Id. at 1152; see Hans, supra note 136, at 1236 (explaining that the interviews show how "jurors struggle with their own responsibility for executing another"); Eisenberg et al., supra note 51, at 352 ("[M]ost jurors accept role responsibility for sentencing.").

Interviews suggesting a lack of responsibility usually involved subjective judgment by a juror based on the appearance of other jurors rather than a confession about the interviewee's own state of mind. Hoffmann, supra note 70, at 1143 ("[I]t bothered me that people were so casual with that kind of responsibility."). There were some, however, who may have interpreted their instructions as dictating their decision: "I had a feeling he was giving us a procedure and we needed to go through these certain steps. And then if all the pieces fit, then you have a responsibility to come back with a death sentence." Id. at 1152.

Interviews did suggest that jury instructions in states using juries merely to provide sentencing recommendations to judges may tend to lessen the juror's individual responsibility or permit the majority to sway a holdout juror in favor of a death sentence. Id. at 1147-51; Hans, supra note 136, at 1238. But if the trial judge who serves as the actual sentencer makes an independent sentencing decision, the jury in fact does not have much, if any, responsibility for the ultimate decision. 
expect to find; he is closer to the juror portrayed in the Caldwell model." $" 141$

\section{F. Evaluating the Radical Subjectivism Critique of Responsibility Theory}

A likely criticism of an individual-responsibility-based theory of capital punishment would portray it as radically subjectivist, substituting the fickle moral judgment of individuals for the firmer moral judgment of society. ${ }^{142}$ Margaret Radin, for example, correctly points out that "some opinions ... [ [are] morally wrong" and that "I want this" or "We [some of us] want this" does not equate to "This is morally justified." The critique fails, however, because it posits a false dichotomy between a firm social morality and ungrounded private morality. On the one hand, social morality is no more than the morality of the individuals in

141. Eisenberg et al., supra note 51 , at 368 . The Milgram model postulates an individual willing to cast aside individual responsibility to follow the instructions of an authority figure. See infra note 147 and accompanying text. The Capital Jury Project showed that jurors did not fit this model.

In summary, responses to several different interview questions suggest a relatively consistent picture of juror sentencing responsibility. The "average" juror understands and accepts the key role he plays in determining the defendant's sentencing; does not view the law as forcing him to reach a particular sentence; does not view a death decision as something that the courts will likely reverse; and finds his service on a capital jury emotionally upsetting. On the other hand, he does not think it very likely that any death sentence he imposes will actually ever be carried out. Finally, although in arriving at a sentence he probably added up and weighed aggravating and mitigating factors, it is unclear that he did so in a fashion which would undermine his responsibility for the sentence imposed. Together, these responses suggest that the "average" juror felt a reasonably firm sense of role responsibility for the sentence he imposed.

Eisenberg et al., supra note 51 at 367-68.

142. Margaret Radin has argued:

Because of the comparative view of proportionality and desert required by equal respect for persons, and because of the allocation of risk of error also required by equal respect for persons, no one can deserve to die when the issue of whether anyone can (ideally) deserve to die is morally uncertain and when in any event it is certain that we cannot select out all and only those who deserve to die.

Margaret Jane Radin, Proportionality, Subjectivity, and Tragedy, 18 U.C. DAVIS L. REv. 1165,1172 (1985). Scott Howe has attacked the Court's doctrine for implicitly assuming that there can be some form of social consensus on what deserts are just in particular cases. Without an articulated standard, he contends, a discretionary system can reduce arbitrariness only if one applies "the unlikely assumption that all capital sentencers would intuitively know and apply an unarticulated substantive standard." Scott W. Howe, The Troubling Influence of Equality in Constitutional Criminal Procedure: From Brown to Miranda, Furman and Beyond, 54 VAND. L. REV. 359, 408 (2001).

143. Radin, supra note 142, at 1171. 
the society. It cannot be more firmly grounded. On the other hand, individual morality can rest on much firmer ground than subjective whim. ${ }^{144}$

The issue is not moral certainty, but moral trust. ${ }^{145}$ We may not trust ourselves to make moral decisions by plebiscite, ${ }^{146}$ yet we may accept our ability to do it as part of a carefully constructed judicial process. But even the structure of a trial may not be enough. Individuals faced with morally difficult choices may see themselves as - in Stanley Milgram's words-"agent[s] for executing the wishes of another person.... In this condition the individual no longer views himself as responsible for his own actions but defines himself as an instrument for carrying out the wishes of others." 147 The responsibility theory thus posits that capital punishment doctrine should create an environment in which we can trust the decisions of each participant in the process, not just the ultimate sentencer, by rendering the decisionmaking process of each one very, very hard. ${ }^{148}$ "The call for something more reassuring-a verifiable formula of moral decision that prescribes future choices[,]" Professor Weisberg concludes, "comes not from moral philosophy, but from the need of the "public order' for political symbols of rationality." 149

Creating a position of trust can be thought of as fostering the conditions under which individuals can tap into a moral grounding to

144. As Robert Weisberg has observed, moral choice is more art than science. Weisberg, supra note 39, at 312 ("For [Harlan], a properly skeptical understanding of the law recognizes two things: first, that many legal decisions cannot be described in or reduced to precise legal language, and second, that those decisions are not for that reason alone arbitrary or irrational.").

145. Cf. JOHN RAWLS, A ThEORY OF Justice 136-42 (1971) (positing that individuals in a presocial state would make moral choices).

146. MAY IT Please THE COURT 229, 236-37 (Peter Irons \& Stephanie Guitton eds., 1993) (reporting that when responding to a question from the Court during the oral argument in Gregg v. Georgia, Anthony Amsterdam argued that neither a public opinion pole nor a plebiscite would be an adequate gauge of the mores of a society, but the Court could nonetheless exercise moral judgment within the structure of the judicial process).

147. STANLEY MILGRAM, OBEDIENCE TO AUTHORITY: AN EXPERIMENTAL VIEW 13334 (1974).

148. One capital juror interviewed about his experience described the jurors' initial frustrations over learning that a defendant they had just sentenced to death had previously been convicted of another murder. One juror was described as saying, "if we would have known this before, this whole thing would have been so easy." The interviewee reported that the judge responded, "That's why we don't tell you. We want to make it difficult. We want to make it fair for him." Hoffmann, supra note 70, at 1155.

149. Weisberg, supra note 39, at 395. 
which they have innate access. ${ }^{150}$ John Rawls draws a useful comparison between the moral sense that we develop and act upon as part of being a participant in a society and the ability of a native speaker of a language to formulate grammatically correct sentences. In each case, we have the skill and use it constantly. Yet, we find describing how we do it difficult, if not impossible. ${ }^{151}$

There are two ways in which this innate ability may work. At the root, the decision may be intuitive. ${ }^{152}$ Both the heinous nature of a particular crime and the background of the defendant may be relevant to the capital sentencing decision. There is no method of valuing and balancing these factors logically. Instead, we must turn to intuition. The idea is not that we simply have the power to intuit morally correct decisions without working at it; rather, we have the ability, by reflecting on our initial intuitive judgments, to take account of morally relevant considerations and constantly reevaluate our conclusions. As Rawls put it, "the best account of a person's sense of justice is not the one which fits his judgments prior to his examining any conception of justice, but rather the one which matches his judgments in reflective equilibrium."153 Under this approach, the role of law is to require the actors in the system to reflect-over and over again-on the decision they are charged with making. By encouraging this reflective process, the doctrine seeks to maximize the intuitive ability of all participants in the process to tap their individual innate moral sensibility.

Alternatively, moral conclusions on capital sentences may be expressive rather than intuitive. That is, we may not figure them out through a process of considering alternatives. We just express what they are. To illustrate this approach, deciding whether a death penalty is appropriate in a particular case could be compared to deciding whether we are in love. The decision is not dictated by any calculus-internal or external-nor can it be corrected by any external source. Yet, it depends

150. RAWLS, supra note 145 , at 50 ("We may suppose that everyone has in himself the whole form of a moral conception.").

151. Id. at 47.

152. The term intuitionist as used herein refers only to the belief that there is no single metastandard for moral decision-making and no method for assigning weights to the separate criteria relevant to moral decision-making.

153. RAWLS, supra note 145 , at 48 ; see GERALD F. GAUS, JUSTIFICATORY LIBERALISM: AN ESSAY ON EPISTEMOLOGY AND POLITICAL THEORY 104 (1996).

After a person has engaged in reflective equilibrium she is almost certain to possess a new set of moral beliefs, different from that with which she started. These differences will be of two types: Some beliefs previously held will be rejected, while some new moral beliefs will enter into her system. These will be inferred from the justified principles; once our beliefs are organized and explained, we can see implications ... of which we were not previously aware.

GAUS, supra, at 104. 
on a social understanding of the word "love" in our language. Just as most of us have access to the resources we need to determine whether we are in love, we may have access to the resources we need to determine whether a death sentence is appropriate. Some of us may be absolutely certain, and some of us may never be sure. Here, the role of law may be an educative one: to ensure that the decisionmakers understand the expressive nature of the task they are performing so that they will access the right tools to express properly-given the rules of language-their moral conclusion. Just as we need to learn not to confuse love and lust, we need to learn not to confuse revulsion and desert.

Whether intuitionist or expressive, one does need to recognize that something may go wrong. The ability of individuals to exercise moral judgment effectively does not guarantee that every judgment will properly tap the individual's moral sensibilities. On the contrary, judgments made when the individual is upset, angry, or overly selfinterested in the decision would be highly unlikely to exhibit the full capacity for moral judgment. ${ }^{154}$ In addition, some individuals may not apply the moral tools accessible to them in good faith, or those tools might not be available to everyone who might come to play a role in capital sentencing. The role of law should be to foster an environment in which we can trust one's moral fiber to shine through. ${ }^{155}$

This Article has shown that, to some extent, modern doctrine does just that by fostering responsibility at each stage so that an error at one stage may be corrected by responsible decision-makers at another. ${ }^{156}$ Most

154. RaWLs, supra note 145 , at 47 .

155. Id. at 47-48 (describing the concept of "considered judgments ... in which our moral capacities are most likely to be displayed without distortion," which Rawls considers those made "under conditions favorable for deliberation and judgment in general").

156. At least some empirical evidence suggests that juries are applying reasonably consistent criteria in determining what evidence suggests a death penalty is appropriate and what evidence is mitigating.

[T] hey say that all victims are of equal worth, although they grant children special consideration. They shudder at sadistic violence, and they show little mercy to defendants who show no remorse. [And, they consider a defendant's potential to take additional lives.] ...

... They attach significant mitigating potential to facts... that show diminished mental capacity..., but they have little patience for defendants who attribute their wrongdoing to drugs or alcohol.

Stephen P. Garvey, Aggravation and Mitigation in Capital Cases: What Do Jurors Think?, 98 COLUM. L. REV. 1538, 1538-39, 1551-66 (1998). They also show some concern for defendants who grew up in poverty or were abused, particularly if they tried to get help. Id. at 1539. 
obviously, appellate review may identify and remedy an irresponsible trial-level sentencing decision. A sentencer can also correct an overzealous prosecution decision, and a prosecutor can weigh the particular facts to refine the legislature's necessarily general decision on when to employ capital punishment. Part IV suggests two ways in which modern doctrine could be expanded to better foster an environment where trust would be possible.

\section{REVISING MODERN DOCTRINE TO COMPORT WITH RESPONSIBILITY THEORY}

Although the structure of modern doctrine broadens responsibility in capital sentencing decisions compared to pre-Furman practice, a specific focus on that goal would lead to significant changes in modern doctrine that would further heighten individual responsibility. ${ }^{157}$ First, the Court should put an end to the hodgepodge of approaches used to instruct sentencing juries. The Court has tended to bless any instructions that do not logically preclude the sentencer from considering and giving effect to mitigating evidence. ${ }^{158}$ This deference has been supported by the notion that modern doctrine's consistency goal is advanced when states structure the sentencer's role. ${ }^{159}$ By focusing on individual responsibility, the pursuit of consistency for its own sake is eliminated, and with it, much of the justification for structuring the sentencer's ultimate decision.

Others have proposed telling sentencers flat out that they are ultimately responsible for the sentence. Implementing these suggestions would be a good start. But it would not be enough. Courts should go

157. James Liebman recently set out an important reform proposal, in the spirit of those advanced here, that would heighten the prosecutor's individual responsibility by imposing a waiting period between indictment and the decision whether to seek a capital sentence, and would require prosecutors to present a detailed report justifying the decision to prosecute capitally. Liebman, supra note 4, at 2144-45.

158. See, e.g., Weeks v. Angelone, 528 U.S. 225, 231-37 (2000) (upholding a death sentence despite potential jury confusion about its ability to impose a life sentence after finding an aggravating circumstance); Buchanan v. Angelone, 522 U.S. 269, 279 (1998) (holding that an "absence of an instruction on the concept of mitigation" was not unconstitutional).

159. See, e.g, Johnson v. Texas, 509 U.S. 350, 361 (1993). The individualization component of modern doctrine

stand(s) only for the proposition that a State may not cut off in an absolute manner the presentation of mitigating evidence, either by statute or judicial instruction, or by limiting the inquiries to which it is relevant so severely that the evidence could never be part of the sentencing decision at all.

Id. "[W] have never concluded that States cannot channel jury discretion in capital sentencing in an effort to achieve a more rational and equitable administration of the death penalty. Much in our cases suggests just the opposite." Franklin v. Lynaugh, 487 U.S. 164, 181 (1988). 
further and replace neutrally worded, declaratory instructions with narratives that set out and legitimize both the government's argument for a death sentence, and the defense's argument against it, clearly and plainly stating that the sentencer has the responsibility to choose between them.

Second, the vague requirement of meaningful appellate review should be fortified by requiring de novo review-the standard of review the Court has often required to safeguard other constitutional values-of every capital sentence. The state court should review the record to determine whether, in its own independent judgment, the judges believe-based on the same criteria applied by the original sentencerthat a death sentence is a morally appropriate response to the defendant's crimes. This proposal is less radical than it might seem; it would merely bring capital punishment doctrine in line with the norm for reviewing mixed constitutional questions of law and fact that are similar in form to capital sentencing decisions.

\section{A. Strengthening Sentencer Responsibility}

Modern doctrine should prohibit instructions and argument that tend to shift responsibility from the sentencer to the legislator, reviewing court, or the community at large. ${ }^{160}$ Recognizing that individuals may

160. Sherman, supra note 50, at $1244-45$.

Trial courts must... forbear making statements or giving instructions suggesting that the jurors' verdict will or may be reviewed or reconsidered by anyone else or that any sentence they impose will or may be overturned or commuted. Prosecutors also, of course, must forbear making arguments that are inconsistent with any of these requirements.

Liebman, supra note 4, at 2148; see Stephen P. Garvey, "As the Gentle Rain from Heaven": Mercy in Capital Sentencing, 81 CORNELL L. REv. 989, 1003 n.56 (1996) ("Capital sentencing juries are said to represent the 'conscience of the community." However, they 'represent' the community only because they are members of the community, not because they discern and then apply community standards.").

An example of the troubling sort of prosecutorial argument that should be prohibited was quoted by the California Supreme Court in People v. Myers:

Your job is a fact-finding process. The law dictates what the penalty shall be depending upon what weight you give, what the total weight is to each aggravating or mitigating circumstance; and you are instructed ... that you are to weigh the aggravating factors against the mitigating factors to determine which weighs the most and then the result is determined by that process. [T] It would not be appropriate for you to determine what result you want to obtain and then seek to shade the factors or the weight to give to the various factors. That would not be fulfilling your duties as a juror, and I am sure each of you will recognize the importance in the jury system of fulfilling your obligation as 
seek ways to avoid responsibility for grave decisions, ${ }^{161}$ capital sentencing doctrine should go beyond prohibiting responsibilitylessening devices and employ techniques designed specifically to reinforce the sentencer's own sense of responsibility. These techniques may be as simple as emphasizing the names of jurors rather than referring to them by number, ${ }^{162}$ or notifying jurors at the start of the sentencing proceeding that each juror must state in open court an individual view on whether this defendant deserves to die. ${ }^{163}$

In addition, courts should seriously consider prohibiting the jury from learning certain information, such as clemency eligibility or that the defendant had previously been sentenced to death. This type of information, even when it correctly reflects the law or historical fact, would tend to undermine the jurors' sense of responsibility without meaningfully contributing to the body of data necessary to a responsible capital sentencing decision. ${ }^{164}$ To date, the Court has explicitly permitted instructions informing the jurors about these matters, as long as the information provided is accurate. ${ }^{165}$ Those decisions should be

a juror and doing that which the law instructs you to do.

729 P.2d 698, 714 (1987). The prosecutor continued:

[Defense counsel] is seeking to inject an element into this matter by saying, remarking that before you kill Mr. Myers, think of this, think of that. [ఖ] Ladies and Gentlemen, the law has been written in a manner and you were voir dired very carefully about this. Your function is a fact-finding function solely, and that has been explained to you very carefully. [T] Once you determine, once you make a determination as to whether or not the aggravating circumstances or factors outweigh those in mitigation or the mitigating circumstances or factors outweigh those in aggravation, then the law says what verdict you shall return. [T] You don't make up your mind as to your preference for penalties. All you are doing is weighing, a weighing process; and the law is very explicit. [9] It is your duty as a juror, if you find that mitigating factors outweigh those in aggravation, it shall be your duty then to return a verdict of life without possibility of parole. [I] If you find that aggravating factors outweigh those in mitigation, it shall be your duty to affix the verdict of the death penalty. You don't determine that. The law has determined that for you. [T] And his statement, 'before you kill Mr. Myers,' is completely inappropriate. The law determines as to what the penalty is and it has always been that way.

Id. at 714 n. 14 .

161. See supra notes 54-57 and accompanying text.

162. Sherman, supra note 50 , at 1246.

163. Liebman, supra note 4 , at 2148 .

164. Gillers, supra note 37, at $1107-10$ (proposing that juries not be informed that their decision will be reviewed or that the alternative to a death sentence may be something less than life in prison); Blaine LeCesne, Tipping the Scales Toward Death: Instructing Capital Jurors on the Possibility of Executive Clemency, 65 U. CIN. L. REv. 1051, 1062-67 (1997).

165. Romano v. California, 512 U.S. 1, 12-13 (1994) (allowing instructions informing jurors about a prior death sentence); California v. Ramos, 463 U.S. 992, 1004 (1983) (allowing instruction pertaining to clemency). 
rethought, at least at the state court level. ${ }^{166}$

In addition, trial courts should explicitly instruct jurors that they must take responsibility for their decision. For example, three commentators have suggested telling the jury "that the decision they are about to make is, despite its legal trappings, a moral one and that, in the absence of legal error, their judgment will be final."167 Another proposes specifically instructing jurors to look to their emotions in making the sentencing decision. ${ }^{168}$

Perhaps more important than the words of the instructions, however, is the voice used by the court in giving those instructions. Legal discourse is expressed in two very different voices that are sometimes called

166. The idea of keeping accurate information from the jury, while perhaps initially unsettling, has a long tradition in the jury system. For example, various rules prohibited juries from being told about the commutation power, the possibility of parole, or appellate review. See, e.g., Ramos, 463 U.S. at 1015 (Marshall, J., dissenting); People v. Morse, 388 P.2d 33, $43-47$ (Cal. 1964); State v. Lindsey, 233 S.E.2d 734, 738 (W.Va. 1977). Similarly, the Court refused to require an instruction under the federal death penalty informing the jury about the effect of a deadlock. Jones v. United States, 527 U.S. 373, 383-84 (1999) (relying on reasoning of the Virginia Supreme Court that "[w]hile this was a correct statement of law it ... was not one which should have been the subject of an instruction" and that "[i]t would have been an open invitation for the jury to avoid its responsibility and to disagree"); see also William J. Bowers \& Benjamin D. Steiner, Death by Default: An Empirical Demonstration of False and Forced Choices in Capital Sentencing, 77 TEX. L. REV. 605, 631-32 (1999); Le Cesne, supra note 164, at 1055-56. While the jury has the unreviewable power to acquit a defendant, neither the court nor the defense are permitted to tell the jury that this power exists. United States v. Dougherty, 473 F.2d 1113, 1136-37 (D.C. Cir. 1972); Weisberg, supra note 39, at $327 \&$ n.89. Of course, rules developed in this context must be applied with caution. For example, while withholding information about parole might be intended to bolster the jurors' sense of responsibility, it could have the opposite effect if jurors assume-as evidence suggests that they do-that defendants are parole-eligible sooner than they in fact are. Bowers \& Steiner, supra, at 645-52, 656. "Jurors grossly underestimate how long capital murderers not sentenced to death usually stay in prison." Id. at 648 .

167. Eisenberg et al., supra note 51, at 379. The authors further propose that jurors should

be expressly told that they are free to impose a life sentence even if they find

the defendant's crime heinous, or the defendant himself to constitute a future danger, and that weighing aggravating and mitigating circumstances is not meant to preempt, or provide a substitute for, the exercise of their own moral judgment in arriving at the defendant's sentence. Finally, jurors might also be instructed that, in the absence of legal error, their decision will not only be final, but also that, if they return a death sentence, their judgment will in the normal course of events ultimately lead to the defendant's execution.

Id. at 379-80.

168. Pillsbury, supra note 40 , at 703-04 ("The courts have an obligation to minimize ... moral error by informing juries of their obligation to try to empathize with the offender as part of assessing deserved punishment."). 
rights-talk, on the one hand, and storytelling or narration, on the other. ${ }^{169}$ When employing rights-talk, a lawyer defines the rights of the relevant parties and describes whether any of those rights have been breached. The decision-maker simply resolves the factual question and allocates the rights. ${ }^{170}$ Any remedy flows directly from that conclusion. Was the contract breached? Was the Fourth Amendment violated? Rights-talk legal arguments often take these familiar forms.

When employing narration, by contrast, the lawyer tells a story about a course of events in the world without the structure of formal rights as a mediating agent. The decision-maker then bears responsibility for supplying the moral criteria necessary to determine the result that should follow from the narrative. ${ }^{171}$ Was the defendant the cause of plaintiff's injury? Would removing a child from the home be in the best interests of the child? ${ }^{172}$ While we do not tend to think of legal disputes as taking this form, these very common ones clearly do.

Robin West has argued that the law calls for storytelling when it needs to "assign or deny responsibility" and with it, moral praise or condemnation. ${ }^{173}$ By contrast, the law calls for rights-talk to confirm "the irrelevance of responsibility."174 For example, a defendant whose privacy has been unlawfully invaded is denied a right-to be free from unreasonable searches-and is entitled to a remedy, regardless of whether the defendant was in any sense responsible for the conditions that led others to violate that right. This effect is not incidental, but rather, it is fundamental to the morality of a rights-based discourse. ${ }^{175}$ All individuals, regardless of apparent worth, are entitled to have their rights respected.

Professor West speculates that a danger of relying too heavily on rights-talk "is that such a society may be dangerously inattentive to the very real need to assign and then acknowledge both individual and societal responsibility for the consequences of actions." 176 She focused her analysis on the use of different voices in appellate capital opinions to evaluate the defendant's responsibility for his predicament. ${ }^{177} \mathrm{Her}$

169. West, supra note 137 , at 161-63.

170. Id.

171. Id.

172. The competing views as to the morality of deciding legal questions through rights-talk or storytelling are concisely presented in West, supra note 137, at 163-66.

173. Id. at 167; see id. at 175 ("[T] he narrative voice ... is the natural and perhaps inevitable means by which responsibility is ascribed.).

174. Id. at 167.

175. Id. at $173 \& \mathrm{n} .40$.

176. Id. at 167.

177. By using the facts of the horrible crimes underlying the cases, West argued that opinions upholding death sentences brought out the defendant's responsibility for the crimes committed. Opinions employing rights-talk, by contrast, rendered the 
insight into the relationship of responsibility and voice, however, could be productively employed during the jury instruction stage to help bolster the jury's sense of responsibility. ${ }^{178}$

Typically, jury instructions are given in the voice of rights-talk. ${ }^{179}$ The jury is told that the defendant has certain rights: the right to be presumed innocent unless the state proves each element beyond a reasonable doubt and the right to an acquittal if the defendant establishes certain affirmative defenses. Modern capital punishment doctrine has borrowed the rights-talk voice for capital sentencing instructions. This is particularly true where the jury is asked to answer a short list of specific questions and return a death verdict if the answer is yes. Here, the message is obvious: "The defendant has a right not to be executed unless the state has convinced you that the answer to the questions is yes." But even in states with more elaborate weighing statutes, the voice of the instructions is overwhelmingly rights-talk. The defendant has a right not to be executed unless the state proves that certain aggravating circumstances exist and outweigh any mitigating circumstances offered by the defendant.

Delivering jury instructions in this voice tends to undermine the jury's sense of responsibility for its role, leading jurors to conclude that their job is to search for historical facts that mediate rights. Put another way, jurors see themselves as puzzle masters, piecing together a puzzle but bearing no real responsibility for deciding where the pieces should go.

Courts could enhance jurors' sense of responsibility by augmenting the instructions defining the defendant's right not to be executed in certain circumstances with a narrative explanation of the jury's role. The judge would begin by explaining the law. The jury would be told that the legislature has decided that no one should be executed unless they fall into one of a set of identified categories. The jury's first job is to decide whether the defendant falls within one or more of those categories by evaluating the facts presented. If the jury believes that to

defendant's responsibility irrelevant to the legitimacy of the death penalty in the cases before them. She faults both sets of opinions for failing to incorporate both voices, which would have enabled the Justices to provide a fuller moral account. Id. at 167-74.

178. Using the narrative voice might also assist jurors in understanding the concepts of aggravating and mitigating evidence. See Tiersma, supra note 120, at 13-23 (citing evidence that jurors do not understand these terms as used in existing capital sentencing instructions).

179. When a trial judge is the sentencer, no instructions are needed. But a judge's decision is informed by the same rights focus that is conveyed by the jury instructions. 
be true, it must go on to its second job of deciding whether to execute this defendant. In contrast to the first inquiry, the judge would emphasize that the legislature has not decided when a particular defendant who has fallen within a category should actually be executed. This decision, the jurors would be told, requires them to do something much different than simply evaluating the facts presented, as they did in deciding if a defendant fits into the specified category. They must decide for themselves, based on the evidence and the narratives that the judge will proceed to read, whether the defendant deserves to die.

After the necessary rights-based instructions, the judge would continue with a short story, provided by the prosecutor, illustrating why the state believes that the defendant should be executed. Next, the court would tell a story of similar length provided by the defense telling why the defendant should not be executed. These narratives would differ significantly from the attorneys' closing arguments because they would not refer to the required findings specified in the state's capital murder statute. Instead, the judge would describe the defendant and the crime using the ordinary language of responsibility, unmediated by legal formalism. The jurors would thus be provided with the stuff of human decision-making that they need to decide, responsibly, whether the defendant should be executed. ${ }^{180}$

180. Professor West has argued that the narrative voice fulfills a need

to understand what happened and why. We need to hear about the event that caused the arrest, about the life circumstances that caused and arguably mitigates the criminality of the event, and the social realities that engendered, facilitated, or permitted the life circumstances. We need to learn once again to recognize these people as human, as "like us." We need that gap of emphatic understanding closed. We need to be given a stake in their lives, and in the communities from which they come. We need to be made responsible.

West, supra note 137 , at 176.

Appropriate narratives would be case- and community-specific. The following truncated examples, in a hypothetical felony-murder case in which the defendant is convicted of murdering a shop owner and injuring his daughter in the course of a robbery, convey the basic idea:

Prosecution: "The defendant went from work to the street that payday, buying alcohol and shooting dice. After a few hours, his week's pay was gone. He lost it to gambling and the bottle, and he was upset about that. So he picked up a shot gun and went to a local convenience store. Then he waited, lying on the ground out of sight. When the owner and his daughter finally emerged from the store, he fired without warning. As the owner was bleeding to death, and his daughter lay on the ground terrified with shot gun pellets in her eyes, the defendant grabbed the money box and ran. And he'd still be running today had we not found his cap near the empty box in the swamp."

Defense: "Before that day, William had no criminal record and a good reputation in the community. People know him as Poochy, and they knew that he was borderline mentally retarded. Yet, he held a job at the gas station, and helped his former wife with the kids. Indeed, if William hadn't confessed to shooting the store owner and his daughter, it would be hard to believe that he did it. But he did confess, because he understood it was wrong to even consider stealing that money. And even more so, he 
The court would follow the narratives by reiterating that the law guides the jury only by focusing its attention on certain factors and enabling it to put aside preconceptions and prejudices that might, perhaps subconsciously, impact an unguided decision. The law does not, by contrast, dictate a result; it cannot tell any individual juror whether a death sentence is appropriate.

\section{B. Strengthening the Meaningful Appellate Review Requirement}

Modern doctrine fails to fulfill the ambitions of the responsibility theory most severely in the way it treats appellate courts. Given our predilection to transfer responsibility for grave decisions, appellate judges are the most vulnerable in the entire capital punishment system. They regularly and systematically defer to trial court and jury decisions in a broad array of contexts, ${ }^{181}$ and they are thus especially likely to side step responsibility for capital sentences by deferring to the trial-level sentencer's decision. In order to maximize appellate judges' sense of responsibility, they should satisfy themselves that the substantive Eighth Amendment standard has been met by reviewing the ultimate sentencing decision de novo, just as appellate courts conduct searching and independent review of similar mixed questions of fact and law in other constitutional contexts. ${ }^{182}$

knows it was wrong to lose control as he did when he started firing that shot gun. The point, though, is that he was not in control. He was under emotional strain, and alcohol surely contributed. And once the shots were fired, he just panicked."

181. Historically, appellate courts have adopted a very deferential stance in reviewing guilty verdicts and, to an even greater extent, sentencing decisions. See Jackson v. Virginia, 443 U.S. 307, 318-19 (1979) (deferential stance in reviewing guilty verdicts); Dorszynski v. United States, 418 U.S. 424, 443 (1974) (explaining that once it is determined that a sentence is within the limits set forth in the statute under which it is imposed, appellate review is at an end).

182. Others have proposed proportionality review-comparisons of cases by an appellate court to minimize aberrational sentences-a suggestion that flows naturally from the consistency goal. See Liebman, supra note 4, at 2148-49; Steiker \& Steiker, supra note 2 , at $414-21$. The substantive review proposed here flows instead from the individual responsibility goal. State appellate courts would not simply compare death sentences in order to identify those that differ in some objective sense from the norm. That requirement would still permit judges to avoid responsibility by relying on trial level conclusions in other cases. Substantive review would require appellate judges to satisfy themselves-by the same means that we ask of jurors and sentencing judges at the trial level-that each defendant is sufficiently more culpable than other first-degree murderers to justify a sentence of death. Cf. Joseph L. Hoffmann, Substance and Procedure in Capital Cases: Why Federal Habeas Courts Should Review the Merits of Every Death Sentence, 78 TEX. L. REV. 1771, 1797 (2000) (contrasting proportionality 
The following subsections first set out the uncertain place that appellate review currently has in modern capital punishment doctrine. They then demonstrate that the Court has routinely encouraged individual responsibility among appellate judges reviewing a wide variety of constitutional questions by demanding that they conduct de novo review to protect constitutional values. The same considerations that motivated the Court in those cases apply to capital punishment, and a similarly rigorous review requirement is thus appropriate. The final subsections describe the dimensions of the review that would be required, in particular, the wisdom of limiting that review to a single state appellate court.

\section{The Role of Appellate Review in Capital Punishment Doctrine}

The initial capital punishment cases emphasized the opportunity for meaningful appellate review as an important factor in upholding the post-Furman statutes. ${ }^{183}$ But the Court later held that proportionality review - the practice of comparing capital cases to guard against aberrational death sentences-is not constitutionally required. ${ }^{184}$ The Court has had very little to say since about the general role of appellate courts in the capital sentencing process. While one could point to passages in certain cases suggesting that some form of meaningful appellate review is required to satisfy the Eighth Amendment, ${ }^{185}$ there

review with de novo substantive review of a type that may differ in some regards from that proposed here).

183. Jurek v. Texas, 428 U.S. 262, 276 (1976) ("By providing prompt judicial review of the jury's decision in a court with statewide jurisdiction, Texas has provided a means to promote the evenhanded, rational, and consistent imposition of death sentences under law."); Proffitt v. Florida, 428 U.S. 242, 251 (1976) (noting that "meaningful appellate review" is made possible by the requirement that the trial judge justify the imposition of a death sentence with written findings and observing that the Florida Supreme Court indicated that it conducted an independent analysis of the aggravating and mitigating circumstances in the particular case); Gregg v. Georgia, 428 U.S. 153, 195 (1976) ("Where the sentencing authority is required to specify the factors it relied upon in reaching its decision, the further safeguard of meaningful appellate review is available to ensure that death sentences are not imposed capriciously or in a freakish manner."). The effectiveness of appellate review during that period may be questioned. See generally George E. Dix, Appellate Review of the Decision to Impose Death, 68 GEO. L.J. 97 (1979); Ellen Liebman, Appellate Review of Death Sentences: A Critique of Proportionality Review, 18 U.C. DAVIS L. REV. 1433 (1985).

Even pre-Furman, the Court suggested that there is a heightened need for review in capital cases. See Griffin v. United States, 336 U.S. 704, 708 (1949) (applying an added requirement in a capital case that the lower court explain the basis for denying a motion to reopen a judgment of conviction based on newly discovered evidence).

184. Pulley v. Harris, 465 U.S. 37, 46 (1984).

185. See, e.g., Clemons v. Mississippi, 494 U.S. 738, 749 (1990) (commenting that "this Court has repeatedly emphasized that meaningful appellate review of death sentences promotes reliability and consistency"). Zant $v$. Stephens upheld a death 
are also passages suggesting that appellate review is not constitutionally required. ${ }^{186}$

In a line of cases dealing with whether appellate courts may uphold death sentences even though the sentencer considered an unconstitutionally vague aggravating circumstance, the Court has expressed concern about overly deferential appellate review. ${ }^{187}$ For example, it has prohibited the automatic affirmance of a death sentence whenever at least one valid aggravating circumstance is found by the sentencer. ${ }^{188}$ Instead, an appellate court must independently review the

sentence where one of three aggravating circumstances was unconstitutionally vague and explained:

Our decision in this case depends in part on the existence of an important procedural safeguard, the mandatory appellate review of each death sentence by the Georgia Supreme Court to avoid arbitrariness and to assure proportionality. We accept that court's view that the subsequent invalidation of one of several statutory aggravating circumstances does not automatically require reversal of the death penalty, having been assured that a death sentence will be set aside if the invalidation of an aggravating circumstance makes the penalty arbitrary or capricious.

Zant v. Stephens, 462 U.S. 862, 890 (1983); see California v. Brown, 479 U.S. 538, 543 (1987); Pulley, 465 U.S. at 45 (stating that "the opinion of Justices Stewart, Powell, and Stevens [in Gregg] suggested that some form of meaningful appellate review is required"); id. at 54 (Stevens, J., concurring) ("I believe the case law does establish that appellate review plays an essential role in eliminating the systemic arbitrariness and capriciousness which infected death penalty schemes invalidated by Furman ..., and hence that some form of meaningful appellate review is constitutionally required."); $i d$. at 59 (Brennan, J., dissenting) ("I]]n each of the statutory schemes approved in our prior cases... meaningful appellate review is an indispensable component of the Court's determination that the State's capital sentencing procedure is valid.").

186. See, e.g., Lowenfield v. Phelps, 484 U.S. 231, 246 (1988) ("There is no question but that the Louisiana scheme narrows the class of death-eligible murderers and then at the sentencing phase allows for the consideration of mitigating circumstances and the exercise of discretion. The Constitution requires no more."); McCleskey v. Kemp, 481 U.S. 279, 306 (1987) (summarizing modern doctrine without reference to any appellate review requirement).

187. Richmond v. Lewis, 506 U.S. 40, 52 (1992); Sochor v. Florida, 504 U.S. 527, 540 (1992); Stringer v. Black, 503 U.S. 222, 230 (1992) ("We require close appellate scrutiny of the import and effect of invalid aggravating factors to implement the wellestablished Eighth Amendment requirement of individualized sentencing determinations in death penalty cases."); Parker v. Dugger, 498 U.S. 308, 322 (1991); Clemons, 494 U.S. at 738 .

188. Clemons, 494 U.S. at 752 ("An automatic rule of affirmance in a weighing State [when at least one valid aggravating circumstance is found by the sentencer] would be invalid under Lockett... [and] Eddings .... for it would not give defendants the individualized treatment that would result from actual reweighing of the mix of mitigating factors and aggravating circumstances."). 
evidence. ${ }^{189}$ Absent constitutional error, however, the Court has suggested that an appellate court may satisfy any meaningful appellate review requirement by merely determining "that the sentencer could have arrived at the death sentence that was imposed." 190 That standard is akin to the sufficiency of the evidence standard and differs markedly from the de novo review applied to the constitutional questions discussed below.

\section{Considering Appellate Review of Capital Cases in Light of the Review Required in Other Constitutional Cases}

The doctrine designed to safeguard the values underlying many constitutional clauses - including key clauses in the First, ${ }^{191}$ Fourth, ${ }^{192}$ Fifth, ${ }^{193}$ Sixth,,${ }^{194}$ Eighth, ${ }^{195}$ and Fourteenth Amendments ${ }^{196}$-requires de novo review of substantive constitutional issues. The Court's failure to impose a similar requirement in capital cases has never been fully explained. This subsection describes the constitutional issues in capital cases and compares them to other cases in which de novo review is required. It concludes that there is no structural difference compelling more deferential review in capital cases. On the contrary, the need for encouraging individual responsibility among appellate judges is, if anything, stronger.

\section{a. The Substantive Constitutional Question in Capital Cases}

Much of modern capital punishment doctrine is procedural. But underlying that procedure is an important substantive core. To satisfy

189. In Clemons, the Court held that an appellate court could satisfy this requirement either by (1) determining beyond a reasonable doubt that the sentencer would have imposed a death sentence (without considering the invalid factors or with properly defined factors) or (2) reweighing the aggravating and mitigating circumstances and making an independent determination that a death sentence is appropriate (again, either ignoring the improper factor or after properly defining it). Id. at 752-53.

190. Id. at 749 .

191. See infra Part IV.B.2.i-ii.

192. See infra Part IV.B.2.b.iii.

193. Thompson v. Keohane, 516 U.S. 99, 116 (1995) (holding that the in custody requirement of the Miranda rule is subject to de novo review).

194. Strickland v. Washington, 466 U.S. 668, 698 (1984) (holding reasonableness of counsel subject to de novo review); Cuyler v. Sullivan, 446 U.S. 335, 341 (1980) (holding potential conflict of interest from multiple representation subject to de novo review); Brewer v. Williams, 430 U.S. 387, 397 \& n.4, 403-04 (1977) (holding waiver of Sixth Amendment right to counsel subject to de novo review).

195. See infra Part IV.B.2.b.iv.

196. See Sumner v. Mata, 455 U.S. 591,597 (1982) (holding sufficiency of pretrial identification procedures subject to de novo review); infra Part IV.B.2.b.v (discussing the due process implications of punitive damages). 
constitutional muster, the Court has held, all sentencing schemes must select a subset of all first-degree murderers who are more deserving of death than others. Merely establishing a procedure that requires the sentencer to find an aggravating circumstance is not enough. "If the sentencer fairly could conclude that an aggravating circumstance applies to every defendant eligible for the death penalty," the Court has explained, "the circumstance is constitutionally infirm." 197 The Court thus struck down a death sentence where it concluded that "[t]he petitioner's crimes cannot be said to have reflected a consciousness materially more 'depraved' than that of any person guilty of murder. ... [As a result t] here is no principled way to distinguish this case, in which the death penalty was imposed, from the many cases in which it was not." 198

Similarly, procedures that merely require the sentencer to consider mitigating evidence are not sufficient. The sentencer must have a means to give effect to that evidence, by imposing a life sentence, to ensure that the substantive requirement-that each death sentence will constitute a reasoned moral conclusion that the defendant is more deserving than

197. Arave v. Creech, 507 U.S. 463, 474 (1993).

Our precedents make clear that a State's capital sentencing scheme also must "genuinely narrow the class of persons eligible for the death penalty." ... When the purpose of a statutory aggravating circumstance is to enable the sentencer to distinguish those who deserve capital punishment from those who do not, the circumstance must provide a principled basis for doing so.

Id. (citations omitted); see Tuilaepa v. California, 512 U.S. 967, 972 (1994) ("[T]he aggravating circumstance... may not apply to every defendant convicted of a murder; it must apply only to a subclass of defendants convicted of murder."); Lewis v. Jeffers, 497 U.S. 764, 776 (1990) ("We have reiterated the general principle that aggravating circumstances must be construed to permit the sentencer to make a principled distinction between those who deserve the death penalty and those who do not."); see also Scott W. Howe, Resolving the Conflict in the Capital Sentencing Cases: A Desert-Oriented Theory of Regulation, 26 GA. L. REV. 323, 418 (1992) ("Regulating capital sentencing under the Eighth Amendment requires a standard to determine when a death sentence in an individual case is just.").

198. Godfrey v. Georgia, 446 U.S. 420, 433 (1980). In McClesky, the Court explained that "there is a required threshold below which the death penalty cannot be imposed. In this context, the State must establish rational criteria that narrow the decisionmaker's judgment as to whether the circumstances of a particular defendant's case meet the threshold." 481 U.S. at 305. As Professor Schopp has explained:

Statutes that narrow the set of death-eligible offenders by selecting only those who qualify as more culpable, more likely to recidivate, or more appropriate for capital punishment according to some other legitimate systemic criterion serve to reduce the number of death-eligible offenders in a manner that justifies the more severe punishment of those selected.

Schopp, supra note 40 , at 482 . 
others-is met. ${ }^{199}$ As the Court recently explained,

the mere mention of "mitigating circumstances" to a capital sentencing jury [does not satisfy] the Eighth Amendment. Nor ... is [it] constitutionally sufficient to inform the jury that it may "consider" mitigating circumstances in deciding the appropriate sentence. Rather, the key ... is that the jury be able to "consider and give effect to [a defendant's mitigating] evidence in imposing sentence." 200

The role of the sentencer in a capital case is thus to determine whether the facts presented at the sentencing trial demonstrate that the defendant is sufficiently more culpable than any other first-degree murderer to justify a death sentence. Even if the proper procedures were in place, a death sentence could nonetheless fail to satisfy the substantive standard if the defendant is not sufficiently culpable to justify death.

\section{b. Other Substantive Constitutional Questions}

Constitutional questions under the Free Speech, Excessive Fines, Cruel and Unusual Punishment, and Due Process Clauses bear almost precisely the same structure as the constitutional issue faced in capital cases. In each case, the Court has established a procedural framework designed to implement a vaguely worded, essentially judge-made substantive constitutional standard that is designed to safeguard the values underlying the particular clause of the Constitution. Each time, the Court has demanded that lower courts engage in de novo review of the substantive question, even though the required procedures were employed.

\section{i. Obscenity}

In the late 1950s, the Court held that obscene speech may be suppressed when it (1) appeals to a prurient interest, (2) is patently offensive, and (3) lacks social value. ${ }^{201}$ The Court initially suggested that there would be little role for appellate courts. If the trial court

199. Penry v. Johnson, 121 S. Ct. 1910, 1920-24 (2001); McKoy v. North Carolina, 494 U.S. 433, 442-43 (1990); Mills v. Maryland, 486 U.S. 367, 383-84 (1988).

200. Penry, 121 S. Ct. at 1920.

201. Roth v. United States, 354 U.S. 476, 484, 487, 492 (1957). The Court later refined the test in Miller v. California, 413 U.S. 15 (1973). The Court declared that:

The basic guidelines for the trier of fact must be: (a) whether "the average person, applying contemporary community standards" would find that the work, taken as a whole, appeals to the prurient interest; . . . (b) whether the work depicts or describes, in a patently offensive way, sexual conduct specifically defined by the applicable state law; and (c) whether the work, taken as a whole, lacks serious literary, artistic, political, or scientific value. Id. at 24 (citations omitted). 
followed the correct procedure, the finder of fact would have the last word-subject to deferential sufficiency of the evidence review. ${ }^{202}$

Justice Harlan wrote a separate opinion cautioning against that approach. The constitutional issue, he wrote, was "not really an issue of fact but a question of constitutional judgment of the most sensitive and delicate kind." 203 Every case involving the suppression of speech "has an individuality and 'value' of its own."204 But that uniqueness, Harlan reasoned, weighed in favor of heightened review, not deference: "[A] reviewing court must determine for itself whether the attacked expression is suppressible within constitutional standards. Since the standards do not readily lend themselves to generalized definitions, the constitutional problem in the last analysis becomes one of particularized judgments which appellate courts must make for themselves." ${ }^{205}$ Harlan concluded with a concern that the majority's approach would "tend to obscure the peculiar responsibilities resting on state and federal courts in this field and encourage them to rely on easy labeling and jury verdicts as a substitute for facing up to the tough individual problems of constitutional judgment involved in every obscenity case."206

Within a few years, the Court came to agree with Justice Harlan that appellate courts could not rely "on a 'sufficient evidence' standard of review," but must instead review the decision de novo. ${ }^{207}$ In the early 1970s, however, the Court reformulated the obscenity test in a way that emphasized an appeal to local community standards that could not be dictated by the state legislature. ${ }^{208}$ Again, doubt was cast on the role of appellate review, but the Court stood firm. Obscenity doctrine, it reiterated, contained a substantive component that appellate courts were required to police. ${ }^{209}$ Requiring juries to decide obscenity cases "in accordance with their own understanding of the tolerance of the average person in their community," the Court explained, "does not mean ... that obscenity convictions will be virtually unreviewable."210 On the

202. Roth, 354 U.S. at $489-92$.

203. Id. at 498 (Harlan, J., concurring and dissenting).

204. Id. at 497.

205. Id.

206. Id. at 498 (emphasis added).

207. See Jacobellis v. Ohio, 378 U.S. 184, 190 \& n.6 (1964) ("[T]his Court cannot avoid making an independent constitutional judgment on the facts of the case as to whether the material involved is constitutionally protected.").

208. Smith v. United States, 431 U.S. 291, 302-03 (1977).

209. Id. at 301,305 .

210. Id. at 305; id. at 301 (applying "community standards does not mean, however, 
contrary, the Court held that "[t]he type of conduct depicted must fall within the substantive limitations suggested" by the Court, and appellate courts had a responsibility to ensure the preservation of constitutional values. ${ }^{211}$

\section{ii. Libel}

In New York Times v. Sullivan, ${ }^{212}$ the Court again adopted an imprecise constitutional standard that asked the trier of fact to make findings based on its understanding of human nature. The Free Speech clause was said to require that, in a libel case, a public figure must prove that the defendant acted with actual malice, that is, purposely published a false statement or exhibited a reckless disregard for the truth. ${ }^{213}$ As in the obscenity cases, the Court imposed a duty on appellate courts to completely and independently examine the record to protect First Amendment values.

The Court's reasoning mirrored that in the obscenity cases. It held that this "rule of independent review assigns to judges a constitutional responsibility that cannot be delegated to the trier of fact." 214 This rule, the Court explained, "reflects a deeply held conviction that judges ... must exercise such review in order to preserve the precious liberties established and ordained by the Constitution."215 This is true even where, if not especially where, the substantive standard is "not readily captured in "one infallible definition.",216

\section{iii. Probable Cause and Reasonable Suspicion}

Before police officers may stop and frisk an individual, the Fourth

that juror discretion in this area is to go unchecked").

211. Id. at 305. For example, in Jenkins v. Georgia, 418 U.S. 153, 159-60 (1974), the Court unanimously rejected the argument that, under Miller, once the jury resolved the obscenity question, the job of the appellate court was merely to determine whether there was sufficient evidence to support it. Justice Rehnquist, writing for the Court, explained that appellate courts retained "the ultimate power... to conduct an independent review of constitutional claims" and "when necessary" they were obligated to exercise that power to preserve First Amendment values. Id. at 160; see also Pope v. Illinois, 481 U.S. 497, 503 (1987); Hamling v. United States, 418 U.S. 87, 160 (1974).

212. 376 U.S. 254 (1964).

213. Id. at $279-80$.

214. Bose Corp. v. Consumers Union of U.S., Inc., 466 U.S. 485, 501 (1984); see Harte-Hanks Communications, Inc. v. Connaughton, 491 U.S. 657, 686 (1989) (" "[J]udges, as expositors of the Constitution," have a duty to "independently decide whether the evidence in the record is sufficient to cross the constitutional threshold ...."' (quoting Bose Corp., 466 U.S. at 511)).

215. Bose Corp., 466 U.S. at 510-11.

216. Harte-Hanks Communications, Inc., 491 U.S. at 686. 
Amendment requires that they must have a reasonable, articuable suspicion that the individual is "armed and dangerous." 217 In order to conduct a full-scale search, the officer must have probable cause to believe that evidence of criminal activity will be found in the place to be searched. ${ }^{218}$ In considering the appropriate standard of review for these constitutional standards, the Court explained that "[a]rticulating precisely what 'reasonable suspicion' and 'probable cause' mean is not possible. They are commonsense, nontechnical conceptions that deal with 'the factual and practical considerations of everyday life on which reasonable and prudent men, not legal technicians, act." 219 The Court distinguished these sorts of legal standards from more precise concepts such as proof beyond a reasonable doubt where greater deference is appropriate. ${ }^{220}$ "[F]luid concepts" like probable cause, the Court explained, "take their substantive content from the particular contexts in which the standards are being assessed,"221 and as a result, one case will seldom serve as precedent for another. ${ }^{222}$ Nevertheless, an appellate court must review the trial decision de novo in order to protect Fourth Amendment values. ${ }^{223}$

\section{iv. Excessive Fines}

The Constitution prohibits a government imposed fine that is "grossly disproportional to the gravity of a defendant's offense."224 That standard is similar, in its lack of precision and its reference to communal values, to the standards applied in other constitutional cases. ${ }^{225}$ Not surprisingly, when the Court recently faced the issue for the first time, it required de novo appellate review despite the case-by-case nature of the inquiry. ${ }^{226}$

\footnotetext{
217. Terry v. Ohio, 392 U.S. 1, 27 (1968).

218. Illinois v. Gates, 462 U.S. 213,235 (1983).

219. Ornelas v. United States, 517 U.S. 690, 695 (1996) (quoting Gates, 462 U.S. at

220. Id. at 696 .

221. Id.

222. Id. at 698 .

223. Id. at 691 .

224. United States v. Bajakajian, 524 U.S. 321, 334 (1998).

225. Id. at 336 (describing the standard as "inherently imprecise").

226. Id. at 336 \& n.10. Perhaps more surprising, however, was the Court's reliance on cases decided under the Cruel and Unusual Punishment Clause to support its decision to require de novo review. Id. at 336 (citing Solem v. Helm, 463 U.S. 277, 288 (1983)) (holding that a term of life in prison for a minor felony constituted cruel and unusual punishment).
} 231). 


\section{v. Punitive Damages}

The Court's treatment of punitive damages perhaps most closely mirrors the development of modern capital punishment doctrine. Historically, civil juries had broad discretion to impose punitive damages just as capital juries had complete discretion to impose death sentences. ${ }^{227}$ In the early 1990s, however, the Court began to build doctrine to govern punitive damages cases just as it had done in the 1970s with respect to capital cases, this time relying on the Due Process Clause. $^{228}$

As a matter of procedure, the Court held, states had to instruct the jury that it must distinguish between compensatory damages, which redress a loss, and punitive damages, which punish the defendant and deter future wrongful conduct. ${ }^{229}$ As a matter of substance, the Court held that punitive damages could not be grossly excessive with respect to the defendant's conduct - the very same substantive standard that it applies under both the Excessive Fines and Cruel and Unusual Punishment Clauses. ${ }^{230}$ During the 2001 term, the Court explicitly required de novo review of the substantive constitutional question. ${ }^{231}$

\section{c. No Meaningful Distinctions Justify More Deferential Review in Capital Cases}

While the Court has never directly distinguished capital cases from other types of constitutional cases with respect to appellate review requirements, potential distinctions suggest themselves: the vagueness of the inquiry, the historical pedigree of the constitutional standard, and the traditional deference accorded to guilt and sentencing determinations.

With respect to vagueness, the imprecise nature of the standard might counsel in favor of deference to the finder-of-fact. Appellate review of a substantive standard that draws on communal values is arguably mere second-guessing by judges more distant from both the presentation of evidence and, probably, the communal values that inform the constitutional decision. ${ }^{232}$ Rigorous review of the procedural regularity

227. Pac. Mut. Life Ins. Co. v. Haslip, 499 U.S. 1, 15-17 (1991).

228. See id. at 18-24.

229. Id. at 19.

230. BMW of North America, Inc. v. Gore, 517 U.S. 559, 562 (1996); TXO Prod. Corp. v. Alliance Res. Corp., 509 U.S. 443, 453-55 (1993) (plurality).

231. Cooper Indus., Inc. v. Leatherman Tool Group, Inc., 121 S. Ct. 1678, 1683 (2001); Honda Motor Co. v. Oberg, 512 U.S. 415, 432 (1994) (holding appellate review constitutionally required without reaching the question of the standard of review).

232. Although the Court has been less open about the role of communal values in capital sentencing than it has been, for example, in the obscenity area, the case law as a whole indicates that communal values must play a role in capital sentencing. Stanford v. 
of the proceeding, one might think, would be the only appropriate role for an appellate court.

As the above survey indicates, however, in dealing with virtually every other serious constitutional question, the Court has not followed that reasoning. ${ }^{233}$ Instead, it has required de novo review of the substantive standard. Vague rules take their meaning from their application rather than their terms. "[T] he content of the rule," the Court explained, "is not revealed simply by its literal text, but rather is given meaning through the evolutionary process of common-law adjudication."234 Where constitutional concepts are "fluid" and "cannot be articulated with precision,"235 independent appellate review is "necessary if appellate courts are to maintain control of, and to clarify, the legal principles"236 and "assure the uniform treatment of similarly situated persons that is the essence of law itself."237

This rationale for heightened review is consistent with the view that appellate judges must take responsibility for safeguarding constitutional values by controlling the development of substantive constitutional norms. Trial-level discretion is critical, but not infallible. Substantive de novo review is thus required. Since capital cases are not structurally different from the aforementioned constitutional cases-in each a trierof-fact must determine whether relevant facts fit within the scope of an

Kentucky, 492 U.S. 361, 379 (1989) (plurality); McClesky v. Kemp, 481 U.S. 279, 310 (1987); Woodson v. North Carolina, 428 U.S. 280, 297-98 (1976); Gregg v. Georgia, 428 U.S. 153, 173, 190 (1976).

233. Constitutional issues on which appellate courts are not required to conduct an independent review are those in which the trial judge has unique access to evidence necessary to make critical credibility determinations. See, e.g., Maggio v. Fulford, 462 U.S. 111, 117 (1983) (discussing competency to stand trial); Patton v. Yount, 467 U.S. 1025,1036 (1984) (discussing juror impartiality).

234. Bose Corp. v. Consumers Union of U.S., Inc., 466 U.S. 485, 502 (1984); Harte-Hanks Communications, Inc. v. Connaughton, 491 U.S. 657, 686 (1989) ("[O]nly through the course of case-by-case adjudication can we give content to these otherwise elusive constitutional standards.").

235. Cooper Industries, $121 \mathrm{~S}$. Ct. at 1685.

236. Id. (quoting Ornelas v. United States, 517 U.S. 690, 697 (1996)); Thompson v. Keohane, 516 U.S. 99, 115 (1995) ("[T] he law declaration aspect of independent review potentially may guide police, unify precedent, and stabilize the law.").

237. Cooper Industries, 121 S. Ct. at 1685 (quoting BMW of North America, Inc. v. Gore, 517 U.S. 559, 587 (1996) (Breyer, J., concurring)). The Court has echoed Justice Stevens' more general concern expressed in an early obscenity case that "the constitutional values protected ... make it imperative that judges ... make sure that it is correctly applied." Bose Corp., 466 U.S. at 502; Harte-Hanks Communications, 491 U.S. at 686 ("[O]nly through the course of case-by-case adjudication can we give content to these otherwise elusive constitutional standards."). 
imprecise judge-made substantive rule that draws on communal values-appellate judge responsibility should be no less important when the defendant's life is at issue than where his privacy or freedom of speech rights are threatened.

As a matter of history, the constitutional standard in capital cases is relatively new and does not emerge readily from the text of the Constitution. But the same could be said of most of these other constitutional standards. The obscenity, libel, and reasonable suspicion standards were developed in the 1950s and 1960s. The grossly excessive standard was not applied to punitive damages and excessive fines until the 1990s. And aside from the Fourth Amendment standards, these other constitutional rules have as little relation to the constitutional text as the capital punishment standard.

A more plausible basis to distinguish capital sentencing would look to the deference extended to a jury that determines a defendant's guilt and a trial judge's sentencing decision in noncapital cases. Neither has been held constitutionally entitled to any appellate review at all. ${ }^{238}$ And while review is universal, it is quite deferential. ${ }^{239}$ However, a capital sentencing decision differs from a guilt determination because it is not constitutionally committed to a jury, and because it is fluid and dependent on communal values to a much greater extent. The Court has recognized this distinction in cases holding that appellate courts may impose a capital sentence when a trial-level error undermines the

238. In an 1894 case, the Court held that the appeal of a criminal conviction "is not now a necessary element of due process of law" and therefore "the right of appeal may be accorded by the State to the accused upon such terms as in its wisdom may be deemed proper." McKane v. Durston, 153 U.S. 684, 687-88 (1894). Today, however, "every state and the federal government provides some means of appellate review for defendants in criminal cases." WAYNe R. LAFAve \& Jerold H. IsRael, Criminal PROCEDURE 863 ( $2 \mathrm{~d}$ ed. 1992). As a result, the Court has not been squarely presented with the issue whether a defendant does have a constitutional right to appeal. The Court has, however, continued to cite with approval McKane's decision that such a right does not exist. Jones v. Barnes, 463 U.S. 745, 751 (1983) ("There is, of course, no constitutional right to an appeal ....”); Ross v. Moffitt, 417 U.S. 600, 611 (1974); Griffin v. Illinois, 351 U.S. 12, 18 (1956).

239. See Jackson v. Virginia, 443 U.S. 307, 318-19 \& n.13 (1979) (holding that the standard of review, when challenging the sufficiency of the evidence in a criminal case, is whether a rational jury could have found each fact necessary to the conviction beyond a reasonable doubt; "this inquiry does not require a court to "ask itself whether $i t$ believes that the evidence at the trial established guilt beyond a reasonable doubt" and "it does not require scrutiny of the reasoning process actually used by the factfinder"). The limited scope of review may be due to a concern that appellate courts should "impinge[] upon 'jury' discretion only to the extent necessary to guarantee the fundamental protection of due process of law." Id. at 319. Three justices in Jackson argued that courts should presume "that trial judges and juries will act rationally and honestly in applying the reasonable-doubt standard, at least so long as the trial is free of procedural error and the record contains evidence tending to prove each of the elements of the offense." Id. at 335 (Stevens, J., concurring). 
original sentence. ${ }^{240}$

To be sure, the Court could logically rely on the tradition of deferential review of judicial sentencing to justify limited review of the substance of a death sentence. The most persuasive counterargument may be that, if the Constitution requires de novo appellate review as a safeguard against excessive fines and unjustifiably high punitive damage awards judged under a case-by-case substantive standard that asks whether they are grossly excessive, then surely a death sentence should be subject to searching appellate review as well.

\section{Defining the Scope of De Novo Review of Capital Cases}

Appellate judges reviewing a capital sentence de novo would make an independent judgment as to whether certain constitutional facts have been established, in the same way that appellate courts reach independent conclusions about whether a libel defendant acted with actual malice or whether a particular fine or punitive damage award is grossly excessive. As in other cases, historical facts found by the trial court or jury would be accepted by the appellate court, particularly where they turned on credibility determinations. But the essential constitutional question - whether this particular defendant is sufficiently more deserving of death than other first-degree murderers-would be reviewed de novo. As a practical matter, appellate courts in capital cases would not ignore a trial-level sentencer's decision, just as an appellate court does not ignore a jury decision that a particular form of speech is obscene. The appellate court should, however, incorporate the prior decision into its own independent calculus rather than defer to that decision.

\section{Limiting the De Novo Review Requirement to State Court}

In contrast to the state appellate de novo review standard proposed here, Professor Hoffman recently argued that federal habeas courts should engage in de novo substantive review of death sentences so that "the imposition of the death penalty is based ... on the continuing moral certainty-at every stage of the post-trial proceedings-that the defendant" deserves to die. ${ }^{241}$ His article was written for a symposium

240. Cabana v. Bullock, 474 U.S. 376, 384-88 (1986).

241. Hoffmann, supra note 182, at 1796. "It is intolerable," he concludes, "for a 
on habeas corpus, but he suggested that substantive review might be required in state direct appeal and postconviction proceedings as well. ${ }^{242}$

While Professor Hoffman's proposal and the one offered here likely arise from the same important concern, his proposal fails to meaningfully explain what he would have habeas courts do, and perhaps for that reason, he fails to take account of considerations that favor placing the only de novo substantive review requirement on a state appellate court. First, his description of what federal habeas courts would actually do is confusing. He suggests both that these judges must tap their own "intuitive moral rationality" but also make an "objective judgment based on an interpretation of the community's moral standards"; "setting aside personal idiosyncrasies"; and "striv[ing] to stand in the shoes of society at large." 243 An appeal to moral intuition is far different from an objective assessment of community standards. In any event, both are problematic.

There is little reason to have confidence in either a federal habeas court's moral intuition or its ability to apply community values. The sentencing trial should be shaped to maximize the responsibility of the sentencer-to create an environment where we can trust the judge or jury's reflective moral intuition-in part because the sentencer is the community and not a visionary objective assessor of the community's moral fiber. ${ }^{244}$ It may be possible to create a similar environment of trust in a state appellate court that regularly applies the same capital sentencing scheme and has insight into the moral structure of the society through the range of state law issues that come before it. That level of trust probably could not be created in federal habeas courts.

Second, Professor Hoffman appreciates the argument that the substantive review he proposes might lessen the original sentencer's sense of responsibility, but he correctly concludes that that risk is minimal and worth taking. ${ }^{245} \mathrm{He}$ is right about that, in part, because when sentencing juries think about appellate review, they probably assume that someone will review their decision de novo. They are likely

habeas court reviewing a state death penalty case to be unable to consider directly ... the sense that the defendant, even though guilty, does not deserve to die for his crime...." Id. at 1793. "The habeas court should be morally responsible for ensuring that each individual death sentence is imposed upon a defendant who is actually guilty and deserves to die." Id. at 1801.

242. Id. at 1797 n.149.

243. Id. at 1798.

244. Garvey, supra note 156 , at 1003 n.56 ("Capital sentencing juries are said to represent the 'conscience of the community.' However, they 'represent' the community only because they are members of the community, not because they discern and then apply community standards.").

245. Hoffman, supra note 182 , at 1799 n.156. 
to continue to believe that no matter what trial judges tell them.

Professor Hoffman fails to appreciate, however, the effect of de novo habeas review on the sense of responsibility of the state appellate courts. If those judges know that there is a federal back-up system, particularly given the political pressures on some state supreme courts, they may leave the dirty work to federal courts. ${ }^{246}$ Additionally, there are reasons to believe that the federal courts will not do that dirty work particularly well. First, federal habeas courts may be too far from the sentence to be capable of conducting the appropriate moral inquiry. To be sure, they may be geographically closer to the local courthouse than the state supreme court. But they do not deal with the range of state law issues that arguably makes the state court more connected with the community imposing the sentence. And, in any event, at least some federal judges will always tend to defer to state court decisions, particularly one as subjective as a capital sentencing decision, because of deep-seated beliefs in federalism and comity. ${ }^{247}$

Professor Hoffman suggests that federal courts may take their responsibility seriously because they will know that the case is almost over. $^{248}$ That is a fair point, but the same could be said of the state appellate court if its decision were the last meaningful line of defense. Changes to the habeas statute should have already alerted state appellate courts that they are much closer to the end than they once were. ${ }^{249}$

A third problem with Professor Hoffman's proposal is that it has no

246. Paul M. Bator posed the concern in the context of federal habeas generally, stating:

I could imagine nothing more subversive of a judge's sense of responsibility, of the inner subjective conscientiousness, which is so essential a part of the difficult and subtle art of judging well, than an indiscriminate acceptance of the notion that all the shots will always be called by someone else.

Paul M. Bator, Finality in Criminal Law and Federal Habeas Corpus for State Prisoners, 76 HARV. L. REV. 441, 451 (1963).

247. To be sure, there are reasons to believe that, as a practical matter, elected state court judges will also fail to take sufficient responsibility for reviewing capital sentences. Federal review to ensure that state appellate courts are taking their responsibility seriously, however, is a better approach then extending substantive review into the federal system.

248. Hoffman, supra note 182, at 1799.

249. The Antiterrorism and Effective Death Penalty Act of 1996, Pub. L. No. 104132,110 Stat. 1214, amended the federal habeas corpus statute to make it harder to obtain federal relief for constitutional violations occurring in state criminal proceedings. Most importantly, the amendment required federal courts to uphold a reasonable state court interpretation of federal law even if that interpretation was erroneous. 28 U.S.C. $\S$ 2254(d)(1)-(2) (Supp. IV 1999). 
logical ending place. If a federal habeas court lets the death sentence stand, then presumably the federal court of appeals and the U.S. Supreme Court must apply the same substantive analysis. But why stop there? Those judges have no monopoly on moral wisdom. Why not ask a passerby on the street in front of the Supreme Court and let that person have the last word? The reason, obviously, is that we would have no reason to trust the moral judgment of a passerby, who is too distant from the community imposing the death sentence. The real issue should be who is best placed so that society can trust their moral judgmentarguably, the original sentencer and possibly a state appellate court. Pushing beyond that simply weakens the system by undermining the sense of responsibility of earlier participants in the process.

\section{CONCLUSION}

Perhaps inevitably, an article that sets out to defend existing doctrine will be read as an apology: a call to accept what we have because the alternative is so much worse. While all that may be true, this Article aspires to a broader purpose: to show that the answer to the death penalty question does not lie in some secret formula that remains to be discovered. Rather, the answer-if there is one-"has been here for a long time already, and only our own blindness and weakness has prevented us from seeing it around us and within us, and kept us from developing it." Who it comes to doctrinal regulation of the death penalty, we are much closer to as good as it gets than we have realized. Future political choices about capital punishment should be made with that in mind.

250. HAVEL, The Power, supra note 74, at 214. 